\title{
A Novel Project Risk Assessment Method Development via AHP- TOPSIS Hybrid Algorithm
}

\author{
Emin Başar Baylan ${ }^{a^{*}}$ \\ ${ }^{a}$ Istanbul Commerce University Industrial Engineering, Istanbul 34840, Turkey
}

\begin{abstract}
In project planning, risk assessment method plays vital role. Poorly assessed project risks cause degeneration at project cost, project completion time, and project output quality and project scope. Each project activity risk influence these project success factors. Implementation performance of a project activity triggers or smooth of its successor's activity risks. Because of this; employing robust and detailed risk assessment methods is important to reach those project goals. In project risk assessment literature, when it is investigated, it is noticed that risk assessment and evaluation methods are only developed at whole project level. Actually, they are not comprehensive enough to evaluate the project risks at activity level. Besides that traditional risk assessment methods such as risk matrix does not able analyze project risk quantitatively. With this motivation, main aim of this study is developing a multi-criteria based decision method which prioritizing project risks at activity level. AHP and TOPSIS method are combined to developed novel method. In this hybrid method, Constructing AHP model is to prioritize work packages with respect to relative importance of project time, project output quality and project cost. Broken down structure of these work packages are used as input for weighted criteria for TOPSIS method. In second layer of this decision method, TOPSIS model is used for prioritizing predetermined activity risks according weighted project work packages success criteria. In the application of this method, a case study approach is followed. In this sense, "Global Furniture Ltd." which is established in Istanbul, Turkey is chosen as a case to apply newly developed model. Results showed that application of AHP-Stochastic TOPSIS Hybrid Algorithm provides a platform that project risks could be analyzed as quantitative and also at project activity level.
\end{abstract}

\section{Keywords:}

Risk Assessment;

TOPSIS;

Project Risk;

MCDM;

Risk Assessment Method.

Article History:

Received: 02 July 2020

Accepted: 28 September 2020

Published: 01 October 2020

\section{1- Introduction}

In project risk management process, one of the most important issues is project risk assessment. Projects may have many types of risks which are technical, financial, managerial, resource and other outer uncontrollable events. Each possible risk has different characteristics and outcomes. Technically, they have impact on project cost, project scope, project quality and project schedule, at different rates. We know from its nature that generally project risks affect project aspects negatively. Willumsen et al. (2019) presents a literature review and an empirical study on "Value creation through project risk management". This empirical study consists of stakeholders interviews and quantitative analysis of them. While doing this survey their main is the perception of project stakeholders on project risk management and value creation. Their study implies that project stakeholders rely on project risk management when they are persuaded on vale creation [1]. Therefore, risk management requires additional time and cost to diminish negative effects of risks. As project budgets and resources are always limited, managers have to determine which resources (financial, human resource or technical) should be allocated to which possible risk events. It requires predicting probability and possible impacts of project risks to prioritize them. Technically, this case generates multi-

\section{* CONTACT: Bbaylan@ ticaret.edu.tr \\ DOI: http://dx.doi.org/10.28991/esj-2020-01239}

(C) 2020 by the authors. Licensee ESJ, Italy. This is an open access article under the terms and conditions of the Creative Commons Attribution (CC-BY) license (https://creativecommons.org/licenses/by/4.0/). 
criteria decision model that assumes criteria as project features and assumes different project risks as decision alternatives.

In the literature, there are some quantitative project risk assessment methods developed to measure the probability and impact of them. Most common used methods are sensitivity analysis, decision tree analysis, tornado diagrams, simulation models and probability-impact risk matrices. Besides that some multi-criteria decision methods are also used to develop project risk assessment and ranking methods.

Risk matrices are one of the most popular risk assessment methods in literature and practice. Simply, its task is to make support the risk manager while classifying risks according to their probability of occurrence and severity on project success. Technically, a risk matrix has two axis [2]. One axis shows severity of risk and the other shows occurrence probability. Risk analyst marks risk event as a spot on the matrix. Its projections on axis indicate importance of risk.

This simple method is handy, but has some weaknesses. Risk matrices can only evaluate certain risks according to whole project. Namely, it does not distinguish the project activities and does not consider the impact of risks on activities separately. Besides that, there are other technical limitations sourced from structure of risk matrices. Risk matrices have only five or four columns or rows. This means each cell represents $20 \%$ or $25 \%$ of severity and probability of risk. This causes the problem of assigning risk events which has different severity and probability on the same cell. This is poor resolution limitation of risk matrix. Risk matrices can mistakenly assign higher qualitative ratings to quantitatively smaller risks. This causes error while assessing a risk. When it comes to resource allocation to avoid risks, in that case, suboptimal resource allocation may occurs. Risk matrices inputs are assigned by subjective decision. There has been no analytic method integrated to risk matrices to make objective decision. Each individual risk analysts interpret risks differently. Thus, ambiguous inputs and outputs are inevitable in this method [3].

Since insufficiencies traditional risk assessment methods, some novel project risk assessment techniques are developed. Kumar Dey proposes a project risk assessment approach which evaluates projects step by step. In his approach, first part is identifying project alternatives, later to prioritize them with AHP (Analytic Hierarchic Process) assuming general project risks as decision criteria. Once the most suitable project is selected, it is evaluated in terms of its own risks without comparing any other projects. If it is not worth going ahead with this project because of its risk level, risks of that project are tried to be mitigate. If it is worth going ahead with it, then work breakdown structure is derived to analyze work package level risks. If these risks are not tolerable, risks are tried to be mitigated otherwise changing the project scope or they abandon the project. Once risk are assessed as unimportant or mitigated, work packages of project are reduced to activity level to make more detail risk analysis. This last step of decision process assesses activity based risks whether they are tolerable or not. If they are tolerable risk mitigation actions are employed otherwise changing project scope or abandoning project expedients are performed again [4].

Construction project financial risk assessment is a typical risk analyze problem. In China, researchers proposed a novel construction project risk assessment model which is based on five major factors and questionnaire report. Those major risk factors are economic risk, politic risks, construction risks, management risks and other risks. Construction projects are assessed by survey participants according to five risk factors with respect to Likert scale. After implementing questionnaire, an $\mathrm{n}$ edged polygon model is employed in which $\mathrm{n}$ is number of risk factors and standardized data assign in polygon. With the help of another transfer function that polygon model is converted into radar model. In n dimensional radar model, it is illustrated risk values of each project. In fact, this decision method does not involve a multi-criteria decision technique, but it may be counted as a mathematical project risk ranking method [5].

High-tech investment projects have great importance and discussions in terms of risk. Liu et al. (2011) propose a risk evaluation method for the high-tech project investment via uncertain linguistic variables. In their study, two important components for high-tech risk assessment are emerged. They are the risk evaluation indicators system and the risk evaluation method. So they develop a high-tech investment project indicator system and risk evaluation model of the high-tech project investment. As risk indicators, they consider financial risk, technical risk, production risk, market risk, management risk, environment risk and their sub-risks. As a risk evaluation model, they use fuzzy modelling instead of crisp modelling unlike their predecessor researchers do. They use to rank the projects according to their risks by using extended ordered weighted averaging [6].

Mousavi et al. (2011) realized that highway projects' data and experts' wisdom in developing countries are insufficient and limited; moreover, statistical distributions of parameters which play significant role in the projects are usually unknown. Basic approaches cannot solve that kind of problems remarkably. To compensate for this lack in highway projects, they perform the non- parametric jackknife re-sampling technique. First step is ranking the risks with a common technique; second step is ranking those risks with jackknife technique. Jackknife rankings are conducive to some rewarding results, such as reduction of standard deviation and normality of data [7]. 
Urban rail transport projects are complex, requires large investment and involves serious risks. Former researches propose qualitative analysis, lack of accurate measurement and evaluation on risks for that sort of projects. Tang et al. (2011) make quantitative analysis and evaluation on risks in urban rail transit projects by taking use of fuzzy network analysis. They establish three level risk evaluation indicator systems for urban rail transit projects. These levels are target level (risk evaluation an in urban rail transit projects), standard level (political risks, economic risks etc.) and factors level permission risks, factors risk etc.). Considering mutual influence between factors and based on risk evaluation indicator system, they construct a fuzzy-ANP network which assumes risk evaluation target as control level, standard level are modeled clusters which they involve factors as influence network. Solution of that ANP model ranks standard level risks and factor level [8].

Build, Operate and Transfer (BOT) projects are important projects for both government and private sector. Askari and Shokrizade (2014) propose an analytic risk ranking method. They make at first, the risks of the BOT projects are identified, and then they rank them according to the project objectives as criteria by three methods. These methods are fuzzy-TOPSIS, fuzzy simple additive weighting and FQFD technique. Outcomes of these techniques consolidated and evaluated with nominal group technique (NGT). Finally they perform failure mode and effect analysis to identify prioritizing and acting on potential failure modes before the failures [9].

Ultra-High Voltage power transmission projects are new generation tasks that reauires large investment, involves great risks that can be caused from electricity. Zhao and Li proposed a risk index structure that determines key risk factors of (UHV) projects. This model based on a cloud model and fuzzy comprehensive evaluation (FCE) method combines the superiority of the cloud model for reflecting randomness and discreteness with the advantages of the fuzzy comprehensive evaluation method in handling uncertain and vague issues [10]. Muriana and Vizzini implement a general quantitative method project risk assessment and mitigation. Their key point of view is determining the risk of the Work Progress Status. Firstly, the performance of the input factors, namely the costs, quality, and time, are detected. As each project phase ends, the actual values of the input factors are detected and compared with that planned and corrective actions are taken for considering the impact of the actual performances on the overall project. They determine the current risk degree of project by Weighted Sum Method. If risk is higher than planned, preventive actions are taken, in order to mitigate the risk of the entire project [11].

With the extension of energy needs energy performance contracting projects gain more importance. These (EPC) projects have large variety of risk factors because of its nature. Production and consumption of energy may always have volatility. Wang et al. (2018) considers that problem and develop a multi-criteria decision-making framework for risk ranking of energy performance contracting project under picture fuzzy environment model. Basically, this model focus two aspects. One is defining interrelationship between criteria and the other is considering bounded rationality of experts which caused by their psychological manner. In their study they combine fuzzy logic and optimization practice that shows it is a strict mathematical model for risk ranking. In their case study, they apply the method to a hotel's energy efficiency retrofit project. After that they claim that the framework is an effective and practical decision tool for risk ranking of (EPC) projects [12]. Complex industrial projects which long implementation time and high cost needs have carried out with high risk levels. Spanish researchers Urgilés et al. (2019) propose a method that make quantitative risks analysis of cost and deadline overruns for hydroelectric project in the Republic of Ecuador by constructing a stochastic simulation model. As result of the case study, they determine rank and probability of risk which can cause overcost and deadline extension [13].

Public private partnership projects are generally big projects that are carried out with some substantial stakeholders. Iranian researches Ahmadabadi and Heravi (2019) realize that there are few studies focused on PPP projects' risk management. They also add that such studies have contributed to risk assessment methodology, most of them have only focused on cost, time and quality. In their study, they construct a structural equation model that assesses risks of PPP-megaprojects through focusing on risk interaction and stakeholders' expectations. That model gives a ranking of possible risks and risk paths for practicing risk response. They apply their method to Khoramabad-Polezal project. Their method ranked 32 identified risks and emerged 8 risk paths of Khoramabad-Polezal project [14]. Energy demand of China is increasing day by day. Therefore, seawater pumped hydro storage project gains big importance. These projects also involves sorts of risks. Wu et al. (2020) develop a risk assessment framework for seawater pumped hydro storage project under three typical public-private partnership management modes. They use linguistic hesitant fuzzy sets based cloud model. These related management modes are seawater pumped hydro storage project (S-PHP), private public partnership mode of seawater pumped hydro storage project (PPP S-PHP) and built operate transfer model of project (BOT). Their risk assessment framework shows that risk level of S-PHS project locates between "Middle High" and "High", and PPP-S-PHS processes relatively low risk degree, of which the BOT-S-PHS is the lowest [15]. Renewable energy projects are generally funded and planned by government in Russia. At that point, Russian researchers Chebotareva et al. (2020) [16] realize that political uncertainties influence hinder of successful development of renewable energy projects. Therefore, energy policy uncertainties causes some financial and managerial risks. Their study presents the results of a theoretical analysis of the main types of state support measures for renewable energy in Russia. Besides that, their framework uses an energy specific logit-model that allows to assess 
the external and internal factors having an impact on default of the Russian RES projects. They analyze risk dynamic of every level of RES projects and measure effectiveness of government agency on supporting these projects. As a complementary analysis for their study, they assess the state support mechanism for zero risk RES projects [16]. Effective cost estimation of rail construction projects is important risk prevention tool for those sorts of projects. Yuan et al. (2020) carry out a research that emerges main risks for international rail construction projects based on the effects of cost-estimating. They gather data from official reports and semi structured interviews to use them on Monte Carlo simulation. Results of study implies that maximum number of working days per week, the minimum wage for a fulltime worker, dealing with construction permits, an inefficient government bureaucracy, and the business costs of crime and violence influence cost estimating performance. In addition to that, their study argues that cost estimation risk effects total investment costs of international rail projects approximately 5.7 to $12.9 \%$ [17].

As it is seen from the literature, most risk assessment method development studies are done for particular project types. However, there are many different kinds of projects. Besides that these methods are only related with general project risks. They do not handle the risks as project activity based. These properties show that these assessment methods have narrow scope in terms of effectiveness. In this paper, a novel multi-criteria decision method based project risk assessment method is introduced which can be performed for every kind of projects. This method offers a more comprehensive approach than traditional analytic risk assessment methods. This novel method contains AHP and TOPSIS method to achieve risk ranking. In literature, AHP and TOPSIS methods are connectively used to create hybrid method for several problems. For example they are connectively used for evaluating ballast water treatment systems by ship operators by Greek researchers [18]. In AHP part of method, time, cost and quality aspects of project are assumed as decision criteria and project work packages are considered as decision alternatives. In pairwise comparison questions, risk experts comment on that, "In which work package they do not want to come across a risk more?" After AHP, work packages are ranked according their risk unwillingness. Afterwards, AHP results of work packages coefficients are distributed on work packages and these coefficients are distributed on quality aspects, time and cost of related project activities. In second part of method TOPSIS method is used. This TOPSIS method considers quality aspects, time and cost of project activities and their calculated importance coefficient as decision criteria. It considers as decision alternatives, risks of project activities which may occur during their implementation. This process ranks project activity risk according to their potential impact on project quality aspects, cost and time. To illustrate how this technique works, a small project is modeled with this AHP-TOPSIS risk ranking method.

\section{2- Project Risk Assessment Process and Motivation for Activity Based Project Risk Assessment Method Development}

Project risk management process involves four steps. First step is analyzing and identify potential project risks. To achieve this job, project risk managers come together with of core team members and other relevant stakeholders. They conduct some workshops by using brainstorming and other problem identifying techniques to bring out potential project risks. They generally consider their past experiences with similar projects and they construct a risk breakdown structure.

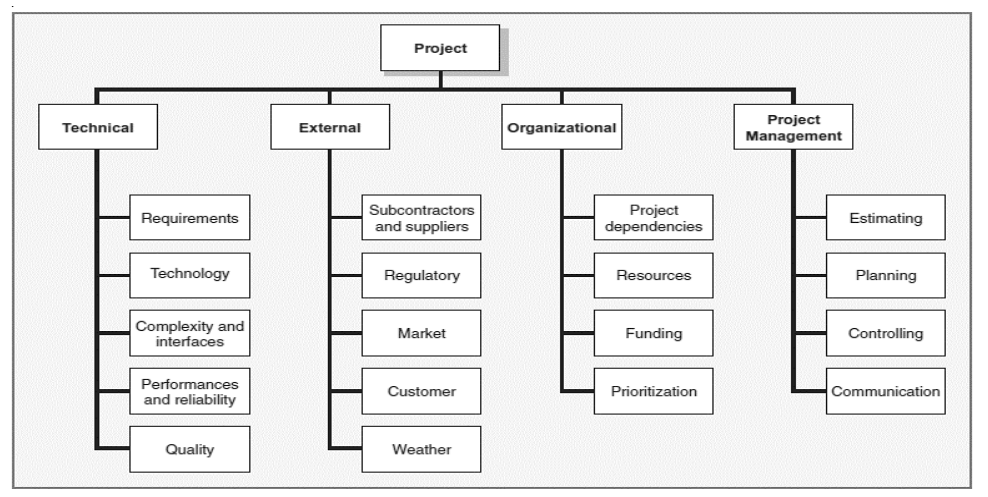

Figure 1. Project Risk Breakdown Structure [19].

With this basic method above, first they determine captions of fundamental risks. Then they break down those captions to more specific project risk captions. For example, project management risk is main caption and its subcaptions are wrong estimating, inefficient planning, and inefficient controlling.

Second step of risk management is assessing project risk in terms of their probability of occurrence and their potential impact on project. In this part, risk management team has to predict value of these aspects. They generally use (1-5) Likert scale.

There is another important job has to be done in that step. Risks must be prioritized in terms of their probability and impact. The reason is projects have limited resources and time allocated for struggling with risk. Thus, risk 
management team have decide "Which project risks worth to eliminate and taken countermeasures against more? "Risk matrix is used to do this ranking.

In risk matrix, horizontal axis represents impact value and vertical axis represents likelihood of projects risk. Projects risks are placed the corresponding cell. There are several zones occurred in risk matrix, which shows importance of risks. In the example, they are indicated. Some zones have seemed equal importance and others have different value. After making risk matrix analysis Failure Mode and Effects Analysis (FMEA) extends the risk severity matrix by including ease of detection in the equation:

\section{Impact $x$ Probability $x$ Detection $=$ Risk Value}

Detection is defined as the ability of the project team to discern that the risk event is imminent. A score of 1 would be given if even a chimpanzee could spot the risk coming. The highest detection score of 5 would be given to events that could only be discovered after it is too late [19]. As it is seen FMEA, which contains risk matrix method analysis completes this traditional risk ranking method.

Third step of risk management is to develop prevention strategies to reduce possible damages of risks. These are mainly;

Mitigating risk: these are most commonly used prevention strategies. They are performed as reducing likelihood that the event will occur and reducing the impact that the adverse event would have on the project.

Avoiding risk: Risk avoiding strategies are performed to eliminate risk or condition.

Transferring Risk: This strategy refers transferring responsibilities and measures of particular risks to another entity.

Sharing Risks: Risk sharing strategies refers allocating the portions of risks to different parties.

Fourth step of risk management is contingency planning. These plans are the actions that reduce or mitigate negative impact of risk event. Due to subject of our study, second step of project risk management is criticized before representing novel project risk assessment method development.

As it is seen from the literature, second step of project risk management process has to be conducted as whole project level due to lack of coverage of risk assessment methods. Risk impacts cannot be measured at activity level. Besides that risk impacts on project parameters, which are likely to be affected from possible risks (project costs, project times, project output quality) cannot be measured in terms of real quantitative values. They only use basic numerical scales, which cannot be considered exactly as quantitative method. However; proper qualitative methods are generally stronger than quantitative methods, which do the same job. From this research, it is understood that there has been no proper quantitative multi-criteria project risk assessment method developed, which examines project risk at activity level and also measures the probable activity quality changes, activity time changes and activity cost changes due to particular activity risks.

In this study, a novel multi-criteria decision method is developed to close the gap in literature. This method is a hybrid method, which has two parts. First part is prioritizing the project activity features that are likely to be affected from project activity risks. Second part is prioritizing the project activity risks according to their impacts on project quality, time and cost features. To achieve this novel method, in first part Analytic Hierarchic Process is used and stochastic TOPSIS method is used.

\section{3- Model Development: Project Activity Risk Prioritization with AHP-Stochastic TOPSIS Hybrid Algorithm}

Multi-Criteria Decision making methods are popular in management issues. Because most management issues require expert opinion and their digitalized form. Managerial decisions are comprehensive decisions that relates whole resources of foundation. Therefore, group decision making models should be employed to carry out this task. MCDM methods are adoptable to group decision making process. These methods can be used making decision about finance, marketing, strategy selection, recruitment decision, project selection, risk ranking etc. [20]. MCDM methods generally consist of three parts. These are goal of decision, criteria and decision alternatives. AHP, ANP, TOPSIS, ELECTRE, VIKOR, PROMETHE, DEMANTEL some of most common methods that are used in literature [21]. Need of hybrid method construction requires to trying to use AHP and TOPSIS models to create a decision support framework for project risk ranking at activity level.

AHP-Stochastic TOPSIS Hybrid method is developed to getting benefit of analyzing project risks at activity level. This approach considers decision criteria as project activity features, which are activity cost, activity time and activity quality aspects and considers project activity risks, which are likely to occur during implementation of activity as 
decision alternatives that are supposed to be prioritized. It is obvious that performing efficiently this method requires predicting project activity features as much realistic as possible. Besides that prospective project activity risk are supposed to be foreseen complete. Once this requirement is satisfied, AHP-Stochastic TOPSIS Hybrid method can be performed efficiently. All steps of this process expressed as below;

- Step 1: First step is defining whole project work as consecutive work packages.

- Step 2: Constructing the work breakdown structure of each work package to derive project activities.

- Step 3: Determining project activity risk that are likely to occur during activity run.

- Step 4: Determining project activity parameters, which are likely to be affected from project activity risks.

- Step 5: Constructing AHP model to prioritize work packages with respect to relative importance of project time, project output quality and project cost. Main idea under this particular model is revealing order of work packages according to their influence on project time, project cost and project quality.

In first layer of AHP model, it is questioned that which project parameter is more important with respect to project contract. Second layer deals with prioritizing work packages with respect project cost, time and output quality.

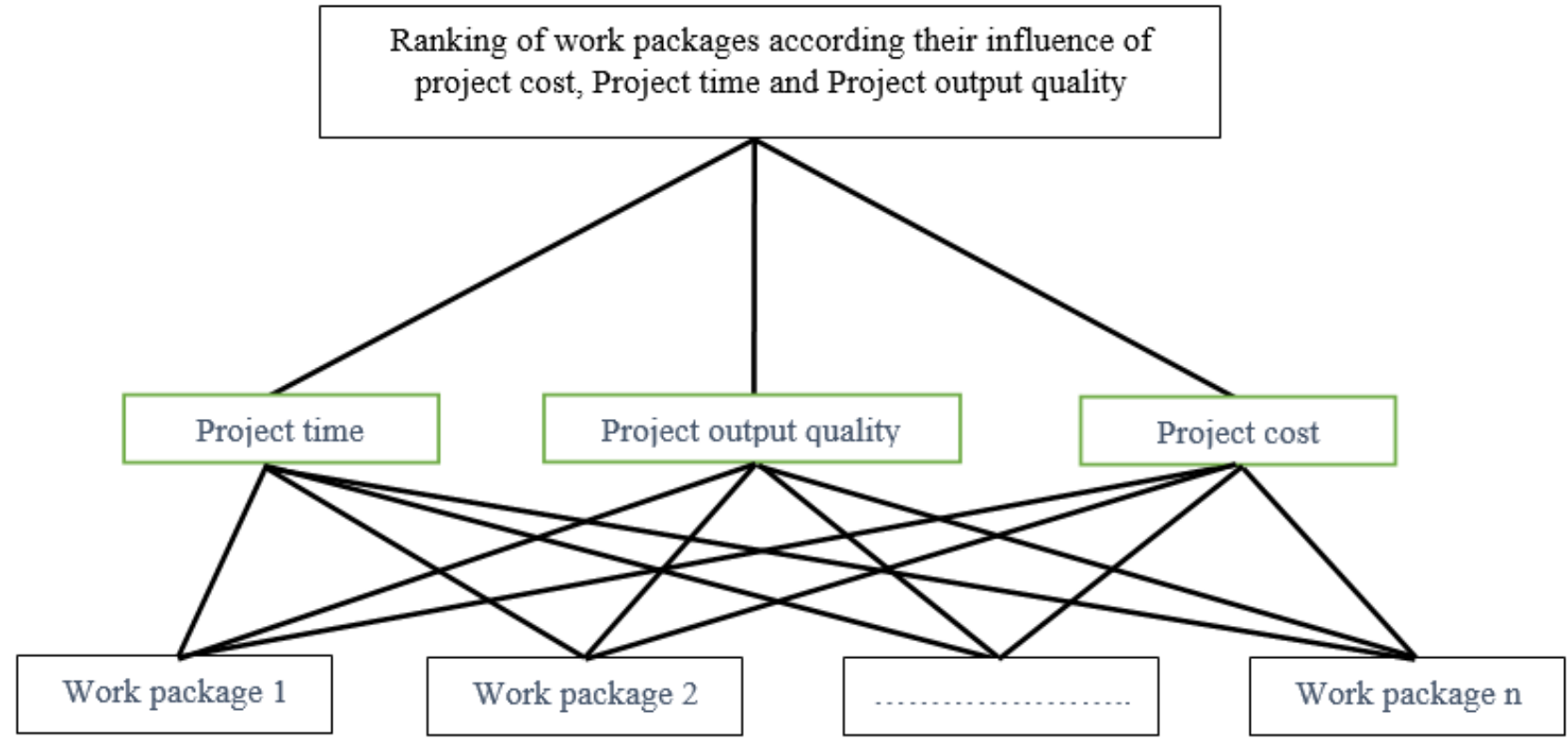

Figure 1. AHP model of work package prioritization process.

In second step work packages were broken into project activities. Namely they are already known. Every related activity have different importance from the perspective of particular work package. Once importance weights of work packages are calculated by AHP, these weight proportions can be distributed to related work package activities.

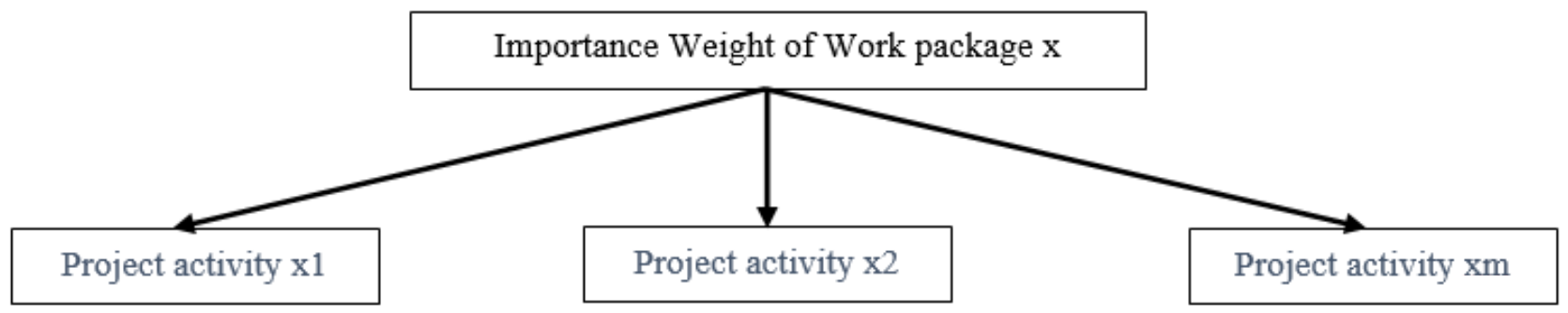

Figure 5. Weight distribution of work package on work package activities.

Importance weight of work package (WWPy)

Weight of project activity of particular work package (WPAx)

$$
\begin{aligned}
& y=1,2, \ldots, n \\
& x=1,2, \ldots, m
\end{aligned}
$$

- Step 6: Each project activity can be affected from risks, which are likely to occur during implementation of activities. Activity parameters are likely to be affected from risks are activity output quality, activity time and activity cost. In this step, implementation time, cost and quality features (they may be more than one) are predicted by the project management team. 
- Step 7: In eighth step, weight of each was derived by distributing the weight of related work package. In this step, similarly weights of activities are distributed on activity parameters. When doing this job, project risk management team has to consider the question that "Which activity parameters should to be far away from risk treats more?" Higher weight values are supposed to be assigned to these particular parameters.

\section{Weight of project activity of particular work package (WPAx)}

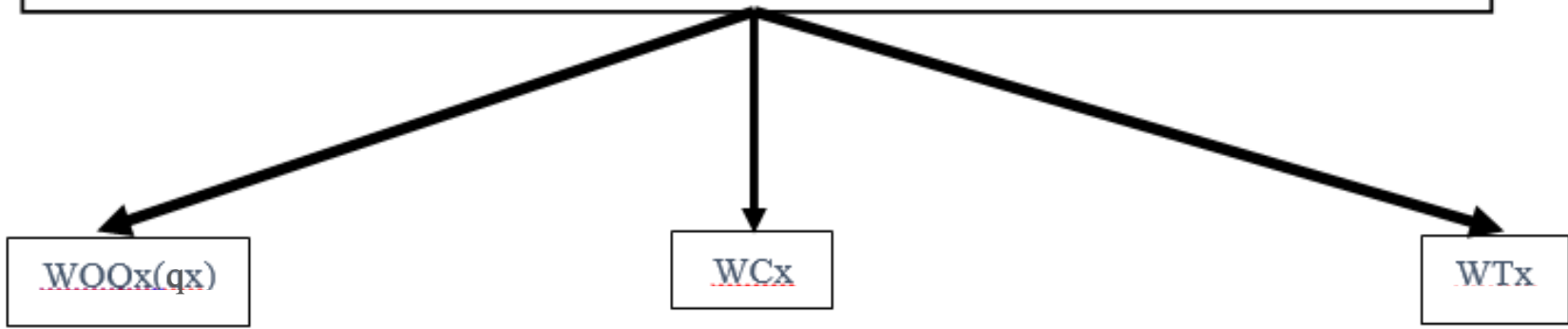

Figure 6. Weight distribution of particular project activity on activity output quality parameters, activity time and activity cost

Weight of activity output quality (WOQx (qx)) $q x=1,2, \ldots$, ax

Weight of activity cost (WCx)

Weight of activity time (WTx)

$\mathrm{x}=1,2, \ldots, \mathrm{m}$

Activity output quality (AOQ x(qx)):

Activity cost (ACx):

Activity time (ATx):

$\mathrm{WPAx}=(\mathrm{WOQx} 1+\mathrm{WOQ} 2+,,,,,,, \mathrm{WOQmz})+\mathrm{WCx}+\mathrm{WTx}$

- Step 8: In this step, project activity risks are predicted and defined. Their probability of occurrence is determined. Impacts of every activity risks (ARr) on every project activity features (activity output quality, project cost and project time) are predicted. This entity is coded as (ARAOQ). This means, every activity have activity time, activity cost and activity output quality parameters. If there no risk treats the activity implementation, it can be implemented in the border of initial predicted cost and expected activity output with desired quality level can be obtained. On the contrary that if a risk occurs and influences the project activity, it can causes increase on activity cost and activity implementation time. Besides that this risk can influence activity output quality through negative direction. These risks affect the activity parameter with the proportion of their probability of occurrence.

$$
\begin{array}{ll}
\text { Project activity (PAx) } & \mathrm{x}=1,2, \ldots, \mathrm{m} \\
\text { Activity risk (ARp) } & \mathrm{p}=1,2, \ldots, \mathrm{r}
\end{array}
$$

Likelihood of activity risks (LARp)

Likelihood of activity risk (LAR) are predicted for every sub-activity risk.

Impact of every activity risk on every project activity quality parameter (ARAOQ) is determined. It is located to intersection of activity risk and project activity parameters on the table. Impact of activity risk on activity times (ARAC) and impact of activity risk on activity times (ARAT) are also predicted.

$$
\begin{array}{ll}
\operatorname{ARAOQx}(\mathrm{pq}): & \mathrm{x}=1,2, \ldots, \mathrm{m} \\
\text { ARACp: } & \mathrm{p}=1,2, \ldots, \mathrm{r} \\
\text { ARATp: } & \mathrm{p}=1,2, \ldots, . \mathrm{r}
\end{array}
$$

q= Every activity have different number of quality parameter. q indicates index of quality parameter of particular ARAOQx 
Table 1. Relationship between activity risks, likelihood of risks and project activity parameters.

\begin{tabular}{|c|c|c|c|c|c|c|c|c|c|c|c|c|}
\hline \multirow{3}{*}{\multicolumn{2}{|c|}{ Project Activity Risks }} & \multirow{4}{*}{$\begin{array}{c}\text { Likelihood of risk } \\
\mathrm{LAR}_{1} \\
\end{array}$} & \multicolumn{10}{|c|}{ Project activity parameters which are possible to be affected from risks } \\
\hline & & & \multicolumn{3}{|c|}{ Activity output quality parameters (AOQ) } & \multirow{3}{*}{\begin{tabular}{|c|}
$\begin{array}{c}\text { Activity cost } \\
\text { (AC) }\end{array}$ \\
$\mathrm{AC}_{1}$ \\
$\mathrm{ARAC}_{11}$ \\
\end{tabular}} & \multirow{3}{*}{\begin{tabular}{|c|}
$\begin{array}{c}\text { Activity time } \\
\text { (AT) }\end{array}$ \\
$\mathrm{AT}_{1}$ \\
$\mathrm{ARAT}_{11}$ \\
\end{tabular}} & \multicolumn{3}{|c|}{$\begin{array}{c}\text { Activity output quality parameters } \\
\text { (AOQ) }\end{array}$} & \multirow{3}{*}{$\begin{array}{c}\begin{array}{c}\text { Activity cost } \\
\text { (AC) }\end{array} \\
\mathrm{AC}_{\mathrm{x}} \\
\mathrm{ARAC}_{\mathrm{x} 1}\end{array}$} & \multirow{3}{*}{$\begin{array}{c}\begin{array}{c}\text { Activity time } \\
\text { (AT) }\end{array} \\
\mathrm{AT}_{\mathrm{x}} \\
\mathrm{ARAT}_{\mathrm{x} 1}\end{array}$} \\
\hline & & & \multirow{2}{*}{$\begin{array}{c}\mathrm{AOQ}_{1(1)} \\
\text { ARAOQ }_{(11)} \\
\end{array}$} & \multirow{2}{*}{$\begin{array}{c}\mathrm{AOQ}_{1(2)} \\
\text { ARAOQ }_{1(21)} \\
\end{array}$} & \multirow{2}{*}{$\begin{array}{l}\cdots \\
\cdots \\
\end{array}$} & & & \multirow{2}{*}{$\begin{array}{c}\mathrm{AOQ}_{\mathrm{x}(1)} \\
\mathrm{ARAOQ}_{\mathrm{x}(11)}\end{array}$} & \multirow{2}{*}{$\begin{array}{c}\mathrm{AOQ}_{\mathrm{x}(\mathrm{pq})} \\
\text { ARAOQ }_{\mathrm{x}(21)}\end{array}$} & \multirow{2}{*}{$\begin{array}{l}\cdots \\
\ldots \\
\end{array}$} & & \\
\hline \multirow{4}{*}{$\mathrm{PA}_{1}$} & $\mathrm{AR}_{1}$ & & & & & & & & & & & \\
\hline & $\mathrm{AR}_{2}$ & $\mathrm{LAR}_{2}$ & $\mathrm{ARAOQ}_{1(12)}$ & $\mathrm{ARAOQ}_{1(22)}$ & $\ldots$ & ARAC $_{12}$ & ARAT $_{12}$ & $\mathrm{ARAOQ}_{\mathrm{x}(12)}$ & $\mathrm{ARAOQ}_{\mathrm{x}(22)}$ & ... & $\operatorname{ARAC}_{\mathrm{x} 2}$ & $\operatorname{ARAT}_{x 2}$ \\
\hline & $\mathrm{AR}_{3}$ & $\mathrm{LAR}_{3}$ & $\mathrm{ARAOQ}_{1(13)}$ & $\mathrm{ARAOQ}_{1(23)}$ & $\ldots$ & $\mathrm{ARAC}_{13}$ & $\mathrm{ARAT}_{13}$ & $\operatorname{ARAOQ}_{\mathrm{x}(13)}$ & $\mathrm{ARAOQ}_{\mathrm{x}(23)}$ & $\ldots$ & $\mathrm{ARAC}_{\mathrm{x} 3}$ & $\operatorname{ARAT}_{x 3}$ \\
\hline & $\mathrm{AR}_{4}$ & $\mathrm{LAR}_{4}$ & $\mathrm{ARAOQ}_{1(14)}$ & $\mathrm{ARAOQ}_{1(24)}$ & $\ldots$ & $\mathrm{ARAC}_{14}$ & $\operatorname{ARAT}_{14}$ & ARAOQ $_{x(14)}$ & ARAOQ $_{x(24)}$ & $\ldots$ & $\operatorname{ARAC}_{\mathrm{x} 4}$ & $\operatorname{ARAT}_{x 4}$ \\
\hline \multirow{4}{*}{$\mathrm{PA}_{2}$} & $\mathrm{AR}_{5}$ & $\mathrm{LAR}_{5}$ & ARAOQ $_{1(15)}$ & $\mathrm{ARAOQ}_{1(25)}$ & $\ldots$ & ARAC $_{15}$ & $\mathrm{ARAT}_{15}$ & ARAOQ $_{x(15)}$ & ARAOQ $_{\mathrm{x}(25)}$ & $\ldots$ & ARAC $_{x 5}$ & $\operatorname{ARAT}_{x 5}$ \\
\hline & $\mathrm{AR}_{6}$ & $\mathrm{LAR}_{6}$ & $\operatorname{ARAOQ}_{1(16)}$ & $\mathrm{ARAOQ}_{1(26)}$ & $\ldots$ & $\mathrm{ARAC}_{16}$ & $\mathrm{ARAT}_{16}$ & $\operatorname{ARAOQ}_{\mathrm{x}(16)}$ & $\mathrm{ARAOQ}_{\mathrm{x}(26)}$ & $\ldots$ & $\operatorname{ARAC}_{x 6}$ & $\operatorname{ARAT}_{x 6}$ \\
\hline & $\mathrm{AR}_{7}$ & $\mathrm{LAR}_{7}$ & ARAOQ $_{1(17)}$ & ARAOQ $_{1(27)}$ & $\ldots$ & $\mathrm{ARAC}_{17}$ & $\mathrm{ARAT}_{17}$ & ARAOQ $_{x(17)}$ & ARAOQ $_{x(27)}$ & $\ldots$ & $\operatorname{ARAC}_{x 7}$ & $\mathrm{ARA}_{\mathrm{x} 7}$ \\
\hline & $\ldots \ldots$. & $\ldots \ldots$. & $\ldots \ldots$. & $\ldots .$. & $\ldots$ & $\ldots \ldots$. & $\ldots \ldots$. & $\ldots .$. & $\ldots \ldots$. & $\ldots$ & $\ldots \ldots$. & $\ldots \ldots$. \\
\hline \multirow{4}{*}{...... } & $\ldots \ldots$. & $\ldots \ldots$. & $\ldots \ldots$. & $\ldots \ldots$. & $\ldots$ & $\ldots \ldots$ & $\ldots \ldots$. & $\ldots \ldots$. & $\ldots \ldots$ & $\ldots$ & $\ldots . .$. & $\ldots \ldots$ \\
\hline & $\ldots . .$. & $\ldots \ldots$. & $\ldots \ldots$. & $\ldots \ldots$. & $\ldots$ & $\ldots \ldots$. & $\ldots . .$. & $\ldots . .$. & $\ldots . .$. & $\ldots$ & $\ldots \ldots$ & $\ldots . .$. \\
\hline & $\ldots . .$. & $\ldots \ldots$. & $\ldots \ldots$ & $\ldots \ldots$. & $\ldots$ & $\ldots . .$. & $\ldots \ldots$. & $\ldots \ldots$. & $\ldots \ldots$ & $\ldots$ & $\ldots \ldots$. & $\ldots \ldots$ \\
\hline & $\ldots \ldots$ & $\ldots \ldots$ & $\ldots \ldots$. & $\ldots .$. & $\ldots$ & $\ldots \ldots$ & $\ldots \ldots$ & $\ldots \ldots$ & $\ldots \ldots$ & $\ldots$ & $\ldots \ldots$. & $\ldots \ldots$ \\
\hline \multirow{4}{*}{$\mathrm{PA}_{\mathrm{m}}$} & $\ldots \ldots$ & $\ldots \ldots$. & $\ldots \ldots$ & $\ldots \ldots$ & $\ldots$ & $\ldots \ldots$ & $\ldots \ldots$ & $\ldots \ldots$ & $\ldots . .$. & $\ldots$ & $\ldots .$. & $\ldots . .$. \\
\hline & $\ldots . .$. & $\ldots . .$. & $\ldots . .$. & $\ldots .$. & $\ldots$ & $\ldots . .$. & $\ldots . .$. & $\ldots . .$. & $\ldots . .$. & $\ldots$ & $\ldots . .$. & $\ldots . .$. \\
\hline & $\ldots \ldots$ & $\ldots \ldots$. & $\ldots \ldots$ & $\ldots \ldots$. & $\ldots$ & $\ldots \ldots$. & $\ldots \ldots$ & $\ldots \ldots$ & $\ldots \ldots$. & $\ldots$ & $\ldots \ldots$. & $\ldots \ldots$ \\
\hline & $\mathrm{AR}_{\mathrm{r}}$ & $\mathrm{LAR}_{\mathrm{r}}$ & ARAOQ $_{1(1 \mathrm{r})}$ & ARAOQ $_{1(2 \mathrm{r})}$ & $\ldots$ & $\mathrm{ARAC}_{1 \mathrm{r}}$ & ARAT $_{1 \mathrm{r}}$ & ARAOQ $_{x(1 \mathrm{r})}$ & $\mathrm{ARAOQ}_{\mathrm{x}(\mathrm{rq})}$ & $\ldots$ & ARAC $_{x r}$ & ARAT $_{x r}$ \\
\hline
\end{tabular}

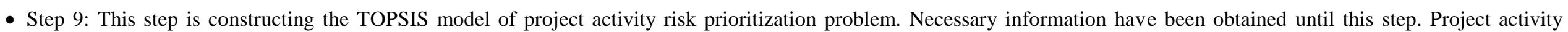
parameters are considered as decision criteria and project activity risks are considered as decision alternatives.

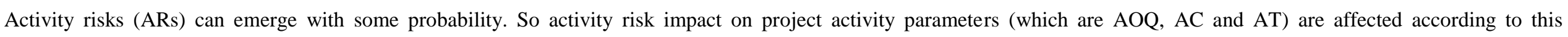

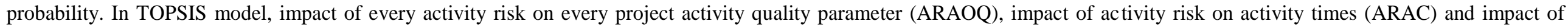

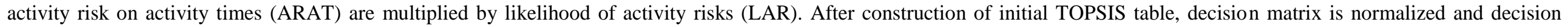
criteria are weighted. 


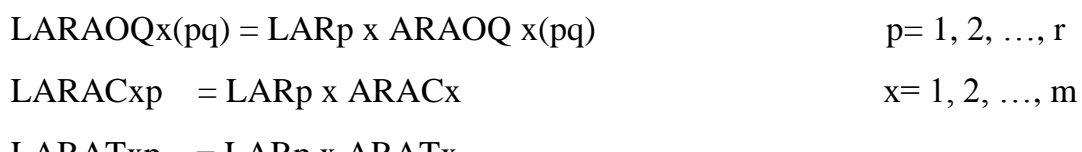

LARATxp $=$ LARp $x$ ARATx

Sum of square of LARAOQ x(pq), LARACxp are LARATxp calculated to normalize TOPSIS table.

$\operatorname{SSOQx}(\mathrm{p} 1)=\sum_{p=1}^{r}\left(\operatorname{LARAOQ}_{\mathrm{x}(\mathrm{p} 1)}\right)^{2} \quad \mathrm{SSx}(\mathrm{p} 2)=\sum_{p=1}^{r} \operatorname{LARAOQ}_{\mathrm{x}(\mathrm{p} 2)}$

Sum of square of LARAOQ $\mathrm{x}(\mathrm{pq})$ values are calculated for every activity output risk and, with respect to their $\mathrm{q}$ values.

$\mathrm{SSCxp}=\sum_{p=1}^{r}\left(\text { LARAC }_{\mathrm{xp}}\right)^{2} \quad$ Sum of square of LARACxp is calculated for every activity cost risk

$\operatorname{SSTxp}=\sum_{p=1}^{r}\left(\operatorname{LARAT}_{\mathrm{xp}}\right)^{2} \quad$ Sum of square of LARATxp is calculated for every activity time risk

To normalize LARAOQx(pq), LARACxp and LARATxp values, they have to be divided by square root of corresponding SSOQ, SSC or SST values. These calculated values are need in normalized TOPSIS table.

$\operatorname{NLARAOQ} x(\mathrm{p} 1)=\frac{\operatorname{LARAOQ}_{\mathrm{x}(\mathrm{p} 1)}}{\sqrt[2]{\operatorname{SSOQ}_{\mathrm{x}(\mathrm{p} 1)}}} \quad \operatorname{NLARAOQx}(\mathrm{p} 2)=\frac{\operatorname{LARAOQ}_{\mathrm{x}(\mathrm{p} 2)}}{\sqrt[2]{\operatorname{SSOQ}_{\mathrm{x}(\mathrm{p} 2)}}}$

NLARACXp $=\frac{\text { LARAC }_{\mathrm{xp}}}{\sqrt[2]{\mathrm{SSC}_{\mathrm{xp}}}}$

NLARATxp $=\frac{\operatorname{LARAT}_{\mathrm{xp}}}{\sqrt[2]{\mathrm{SST}_{\mathrm{xp}}}}$

Weights of project activity parameters are multiplied by related project activity parameter.

WNLARAOQx $(\mathrm{pq})=\mathrm{WOQ}(\mathrm{qx}) \times \mathrm{NLARAOQx}(\mathrm{pq})$

WNLARACxp $=($ WCx $) \times$ NLARACxp

WNLARATxp $=($ WTx $) \times$ NLARATxp 
Table 2. Normalized and weighted TOPSIS mode activity risk prioritization problem.

\begin{tabular}{|c|c|c|c|c|c|c|c|c|c|c|}
\hline \multirow{3}{*}{ 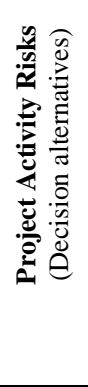 } & \multicolumn{10}{|c|}{ Project activity parameters which are possible to be affected from risks (Decision Criteria) } \\
\hline & \multicolumn{3}{|c|}{ Activity output quality parameters (AOQ) } & \multirow{2}{*}{$\begin{array}{c}\begin{array}{c}\text { Activity cost } \\
\text { (AC) }\end{array} \\
\text { WAC }_{1}\end{array}$} & \multirow{2}{*}{$\begin{array}{c}\begin{array}{c}\text { Activity time } \\
\text { (AT) }\end{array} \\
\text { WAT }_{1}\end{array}$} & \multicolumn{3}{|c|}{$\begin{array}{c}\text { Activity output quality } \\
\text { parameters (AOQ) }\end{array}$} & \multirow{2}{*}{$\begin{array}{c}\begin{array}{c}\text { Activity cost } \\
\text { (AC) }\end{array} \\
\text { WAC }_{x}\end{array}$} & \multirow{2}{*}{$\begin{array}{c}\begin{array}{c}\text { Activity time } \\
\text { (AT) }\end{array} \\
\text { WAT }_{\mathbf{x}}\end{array}$} \\
\hline & $\mathrm{WAOQ}_{1(1)}$ & $\mathrm{WAOQ}_{1(2)}$ & $\ldots$ & & & $\mathrm{WAOQ}_{\mathbf{x}(1)}$ & $\mathbf{W A O Q}_{\mathbf{x}(2)}$ & $\ldots$ & & \\
\hline $\mathbf{A R}_{\mathbf{1}}$ & WNLARAOQ $_{(11)}$ & WNLARAOQ $_{1(21)}$ & $\ldots$ & WNLARAC $_{11}$ & WNLARAT $_{11}$ & WNLARAOQ $_{\mathrm{x}(11)}$ & WNLARAOQ $_{\mathrm{x}(21)}$ & $\ldots$ & WNLARAC $_{\mathrm{x} 1}$ & WNLARAT $_{\mathrm{x} 1}$ \\
\hline $\mathbf{A} \mathbf{R}_{2}$ & WNLARAOQ $_{1(12)}$ & WNLARAOQ $_{1(22)}$ & $\ldots$ & WNLARAC $_{12}$ & WNLARAT $_{12}$ & WNLARAOQ $_{x(12)}$ & WNLARAOQ ${ }_{\mathrm{x}(22)}$ & $\ldots$ & WNLARAC $_{\mathrm{x} 2}$ & WNLARAT $_{\mathrm{x} 2}$ \\
\hline $\mathbf{A} \mathbf{R}_{3}$ & WNLARAOQ $_{1(13)}$ & WNLARAOQ $_{1(23)}$ & $\ldots$ & WNLARAC $_{13}$ & WNLARAT $_{13}$ & WNLARAOQ $_{x(13)}$ & WNLARAOQ $_{\mathrm{x}(23)}$ & $\ldots$ & WNLARAC $_{\mathrm{x} 3}$ & WNLARAT $_{\mathrm{x} 3}$ \\
\hline $\mathbf{A} \mathbf{R}_{4}$ & WNLARAOQ $_{1(14)}$ & WNLARAOQ $_{1(24)}$ & $\ldots$ & WNLARAC $_{14}$ & WNLARAT $_{14}$ & WNLARAOQ $_{x(14)}$ & WNLARAOQ $_{\mathrm{x}(24)}$ & $\ldots$ & WNLARAC $_{\mathrm{x} 4}$ & WNLARAT $_{\mathrm{x} 4}$ \\
\hline \multirow[t]{4}{*}{$\mathbf{A R _ { 5 }}$} & WNLARAOQ $_{1(15)}$ & WNLARAOQ $_{1(25)}$ & $\ldots$ & WNLARAC $_{15}$ & WNLARAT $_{15}$ & WNLARAOQ $_{x(15)}$ & WNLARAOQ $_{\mathrm{x}(25)}$ & $\ldots$ & WNLARAC $_{\mathrm{x} 5}$ & WNLARAT $_{\mathrm{x} 5}$ \\
\hline & $\ldots \ldots$ & $\ldots \ldots$ & $\ldots$ & $\ldots \ldots$ & $\ldots \ldots$ & $\ldots \ldots$ & $\ldots \ldots$ & $\ldots$ & $\ldots \ldots$ & $\ldots \ldots$ \\
\hline & $\ldots \ldots$ & $\ldots \ldots$ & $\ldots$ & $\ldots \ldots$ & $\ldots \ldots$ & $\ldots \ldots$ & $\ldots \ldots$ & $\cdots$ & $\ldots \ldots$ & $\ldots \ldots$ \\
\hline & $\ldots .$. & $\ldots .$. & $\ldots$ & $\ldots \ldots$ & $\ldots .$. & $\ldots \ldots$. & $\ldots \ldots$. & $\ldots$ & $\ldots .$. & $\ldots \ldots$. \\
\hline $\mathbf{A} \mathbf{R}_{\mathrm{m}}$ & WNLARAOQ $_{1_{(1) \mathrm{r}}}$ & WNLARAOQ $_{1(2) \mathrm{r}}$ & $\ldots$ & WNLARAC $_{1 \mathrm{r}}$ & WNLARAT $_{1 \mathrm{r}}$ & WNLARAOQ $_{x(1 \mathrm{r})}$ & WNLARAOQ $_{x(a r)}$ & $\ldots$ & WNLARAC $_{\mathrm{xr}}$ & WNLARAT $_{\mathrm{xr}}$ \\
\hline$A \boldsymbol{R}_{x}^{*}$ & $\begin{array}{l}\text { WAOQ }_{1(1)}^{*}=\mathrm{Max} \\
\text { WNLARAOQ }_{1(\mathrm{la})}\end{array}$ & $\begin{array}{l}\text { WAOQ }_{1(2)}^{*}=\mathrm{Max}^{*} \\
\text { WNLARAOQ }_{1(2 q)}\end{array}$ & $\cdots$ & $\mathrm{WAC}_{1}^{*}=$ MaxWNLARAC $\mathrm{Cp}_{\mathrm{p}}$ & $\mathrm{WAT}_{1}^{*}=\mathrm{MaxWNLARAT}_{\mathrm{lp}}$ & $\begin{array}{l}\text { WAOQ }_{\mathrm{x}(1)}{ }_{1}^{*}=\text { Max } \\
\text { WNLARAOQ }_{\mathrm{x}(1 \mathrm{q})}\end{array}$ & $\cdots \cdots$ & $\cdots$ & $\begin{array}{l}\text { WAC }_{x_{1}}^{*}=\mathrm{Max} \\
\text { WLARAC }_{x p}\end{array}$ & $\begin{array}{c}\mathrm{WAT}_{x_{1}}^{*}=\mathrm{MaxW} \\
\text { LARAT }_{\mathrm{xp}}\end{array}$ \\
\hline$A R_{x}^{-}$ & $\begin{array}{c}\text { WAOQ }_{1(1)}^{-}=\text {Min } \\
\text { WNLARAOQ }_{1(1 \mathrm{a})}\end{array}$ & $\begin{array}{c}\text { WAOQ }_{1(2)}^{-}=\mathrm{Min}^{-} \\
\text {WNLARAOQ }_{1(2 q)}\end{array}$ & $\cdots$ & $\mathrm{WAC}_{1}^{-}=\operatorname{MinWNLARAC} \mathrm{c}_{\mathrm{p}}$ & $\mathrm{WAT}_{1}^{-}=\mathrm{Min} \mathrm{WNLARAT}_{1 \mathrm{p}}$ & $\begin{array}{l}\text { WAOQ }_{\mathrm{x}(1)}^{-}=\mathrm{Min}_{1} \\
\text { WNLARAOQ }_{\mathrm{x}(1 \mathrm{q})}\end{array}$ & $\cdots \cdots$ & $\cdots$ & $\begin{array}{l}\text { WAC }_{x_{1}}^{-}=\text {Min } \\
\text { WLARAC }_{x p}\end{array}$ & $\begin{array}{c}\mathrm{WAT}_{x_{1}}^{*}=\mathrm{MinW} \\
\text { LARAT }_{\mathrm{xp}}\end{array}$ \\
\hline
\end{tabular}

- Step 10: Determination of positive ideal and negative ideal solutions.

$A R^{*}=\left\{\begin{array}{c}\left(\max _{x}\left(\mathrm{WNLARAOQ}_{x(p q)}, \mathrm{WNLARAC}_{x p}, \mathrm{WNLARAT}_{x p} \mid p \in P\right)\right), \\ \left(\min _{x}\left(\mathrm{WNLARAOQ}_{x(p q)}, \mathrm{WNLARAC}_{x p}, \mathrm{WNLARAT}_{x p} \mid p \in P^{I}\right)\right.\end{array}\right\}, \quad x=1,2, \ldots, m$ 
$A R^{*}=\left\{\right.$ WNLARAOQ $_{1(* q)},,$, WNLARAC $_{1 *}$ WNLARAT $\left._{1 *}\right\}$

$A R^{-}=\left\{\begin{array}{c}\left(\min _{x} \operatorname{WNLARAOQ}_{x(p q)}, \mathrm{WNLARAC}_{x p}, \operatorname{WNLARAT}_{x p} \mid p \in P\right), \\ \left(\max _{x}\left(\operatorname{WNLARAOQ}_{x(p q),} \operatorname{WNLARAC}_{x p}, \operatorname{WNLARAT}_{x p} \mid p \in P^{I}\right)\right.\end{array}\right\}, x=1,2, \ldots \ldots, m$

$A R^{-}=\left\{\right.$WNLARAOQ $_{1(-q)},,$, WNLARAC $_{1-}$, WNLARAT $\left._{1-}\right\}$

To continue TOPSIS algorithm operations, WNLARAOQ, WNLARAC, WNLARAT notations are needed to be changed into (vxj) notations. This transformation matrix below represents the notation equivalence.

$\mathrm{x}=1,2, \ldots \ldots, \mathrm{m} \quad \mathrm{j}=1,2, \ldots \ldots \ldots, \mathrm{n}$

Table 3. Notation transformation table to simply TOPSIS model.

\begin{tabular}{|c|c|c|c|c|c|c|}
\hline \multirow{3}{*}{$\begin{array}{l}\text { Project Activity Risks } \\
\text { (Decision alternatives) }\end{array}$} & \multicolumn{6}{|c|}{ Project activity parameters which are possible to be affected from risks (Decision Criteria) } \\
\hline & \multicolumn{2}{|c|}{ Activity output quality parameters (AOQ) } & \multicolumn{3}{|r|}{ Activity cost (AC) } & \multirow{2}{*}{$\frac{\text { Activity time (AT) }}{\text { WAT }_{\mathbf{n}}}$} \\
\hline & $\mathrm{V}_{1}=\mathrm{WAOQ}_{11}$ & $\mathrm{~V}_{2}=\mathrm{WAOQ}_{12}$ & $\ldots$ & $\ldots$ & WAC $_{n-1}$ & \\
\hline $\mathrm{AR}_{1}$ & $\mathrm{v}_{11}=\mathrm{WNLARAOQ} \mathrm{x}_{(11)}$ & $\mathrm{v}_{12}=\mathrm{WNLARAOQ} \mathrm{x}_{(12)}$ & $\ldots$ & $\ldots$ & $\mathrm{v}_{1(\mathrm{n}-1)}=\mathrm{WNLARAC}_{1(\mathrm{n}-1)}$ & $\mathrm{v}_{1 \mathrm{n}}=\mathrm{WNLARAT}_{1 \mathrm{n}}$ \\
\hline $\mathrm{AR}_{2}$ & $\mathrm{v}_{21}=\mathrm{WNLARAOQ} \mathrm{Q}_{(21)}$ & $\mathrm{v}_{22}=$ WNLARAOQ ${ }_{\mathrm{x}(22)}$ & $\cdots$ & $\cdots$ & $\mathrm{v}_{2(\mathrm{n}-1)}=\mathrm{WNLARAC}_{2(\mathrm{n}-1)}$ & $\mathrm{v}_{2 \mathrm{n}}=\mathrm{WNLARAT}_{2 \mathrm{n}}$ \\
\hline $\mathrm{AR}_{3}$ & $\mathrm{v}_{31}=\mathrm{WNLARAOQ} \mathrm{x}_{\mathrm{x}(31)}$ & $\mathrm{v}_{32}=\mathrm{WNLARAOQ}_{\mathrm{x}(32)}$ & $\ldots$ & $\cdots$ & $\mathrm{v}_{3(\mathrm{n}-1)}=\mathrm{WNLARAC}_{3(\mathrm{n}-1)}$ & $\mathrm{v}_{3 \mathrm{n}}=\mathrm{WNLARAT}_{3 \mathrm{n}}$ \\
\hline $\mathrm{AR}_{4}$ & $\mathrm{v}_{41}=\mathrm{WNLARAOQ} \mathrm{x}_{(41)}$ & $\mathrm{v}_{42}=\mathrm{WNLARAOQ} \mathrm{x}_{(42)}$ & $\ldots$ & $\cdots$ & $\mathrm{v}_{4(\mathrm{n}-1)}=\mathrm{WNLARAC}_{4(\mathrm{n}-1)}$ & $\mathrm{v}_{4 \mathrm{n}}=\mathrm{WNLARAT}_{4 \mathrm{n}}$ \\
\hline $\mathrm{AR}_{5}$ & $\mathrm{v}_{51}=\mathrm{WNLARAOQ} \mathrm{x}_{(51)}$ & $\mathrm{v}_{52}=$ WNLARAOQ ${ }_{\mathrm{x}(52)}$ & $\ldots$ & $\ldots$ & $\mathrm{v}_{5(\mathrm{n}-1)}=\mathrm{WNLARAC}_{5(\mathrm{n}-1)}$ & $\mathrm{v}_{5 \mathrm{n}}=\mathrm{WNLARAT}_{5 \mathrm{n}}$ \\
\hline$\cdots \cdots$ & (............ & (............ & $\cdots$ & $\cdots$ & (............ & (............ \\
\hline ...... & ............ & ............ & $\ldots$ & $\ldots$ & ............ & ............ \\
\hline $\mathrm{AR}_{\mathrm{m}}$ & $\mathrm{v}_{\mathrm{m} 1}=\mathrm{WNLARAOQ} \mathrm{Q}_{\mathrm{x}(\mathrm{m} 1)}$ & $\mathrm{v}_{\mathrm{m} 1}=\mathrm{WNLARAOQ} \mathrm{x}_{\mathrm{x} 2)}$ & $\cdots$ & $\cdots$ & $\mathrm{WNLARAC}_{\mathrm{m}(\mathrm{n}-1)}$ & WNLARAT $_{\mathrm{mn}}$ \\
\hline $\mathbf{A R}_{\mathbf{x}}^{*}$ & $v_{1}^{*}=\operatorname{Max} \mathbf{v}_{\mathbf{x} 1}$ & $v_{2}^{*}=\operatorname{Max} \mathbf{v}_{\mathbf{x} 2}$ & $\ldots$ & $\ldots$ & $v_{n-1}^{*}=\operatorname{Max} \mathbf{v}_{\mathbf{x}(\mathbf{n}-\mathbf{1})}$ & $v_{n}=\operatorname{Max} \mathbf{v}_{\mathbf{x n}}$ \\
\hline $\mathbf{A} \mathbf{R}_{\mathbf{x}}^{-}$ & $v_{1}=\operatorname{Min} \mathbf{v}_{\mathbf{x} 1}$ & $v_{2}=\operatorname{Min} \mathbf{v}_{\mathbf{x} 2}$ & $\ldots$ & $\cdots$ & $v_{n-1}^{-}=\operatorname{Min} \mathbf{v}_{\mathbf{x}(\mathbf{n}-1)}$ & $v_{n}=\operatorname{Min} \mathbf{v}_{\mathbf{x n}}$ \\
\hline
\end{tabular}

- Step 11: This step is calculation of separation measurement. Euclid distance method is used to achieve this process.

$S_{x}^{*}=\sqrt{\sum_{j=1}^{n}\left(v_{x j-} v_{j}^{*}\right)^{2}}, \quad \mathrm{x}=1,2, \ldots, \mathrm{m}$
$S_{x}^{-}=\sqrt{\sum_{j=1}^{n}\left(v_{x j-} v_{j}^{-}\right)^{2}}, \quad \mathrm{x}=1,2, \ldots, \mathrm{m}$

Table 4. Ideal separation measurements.

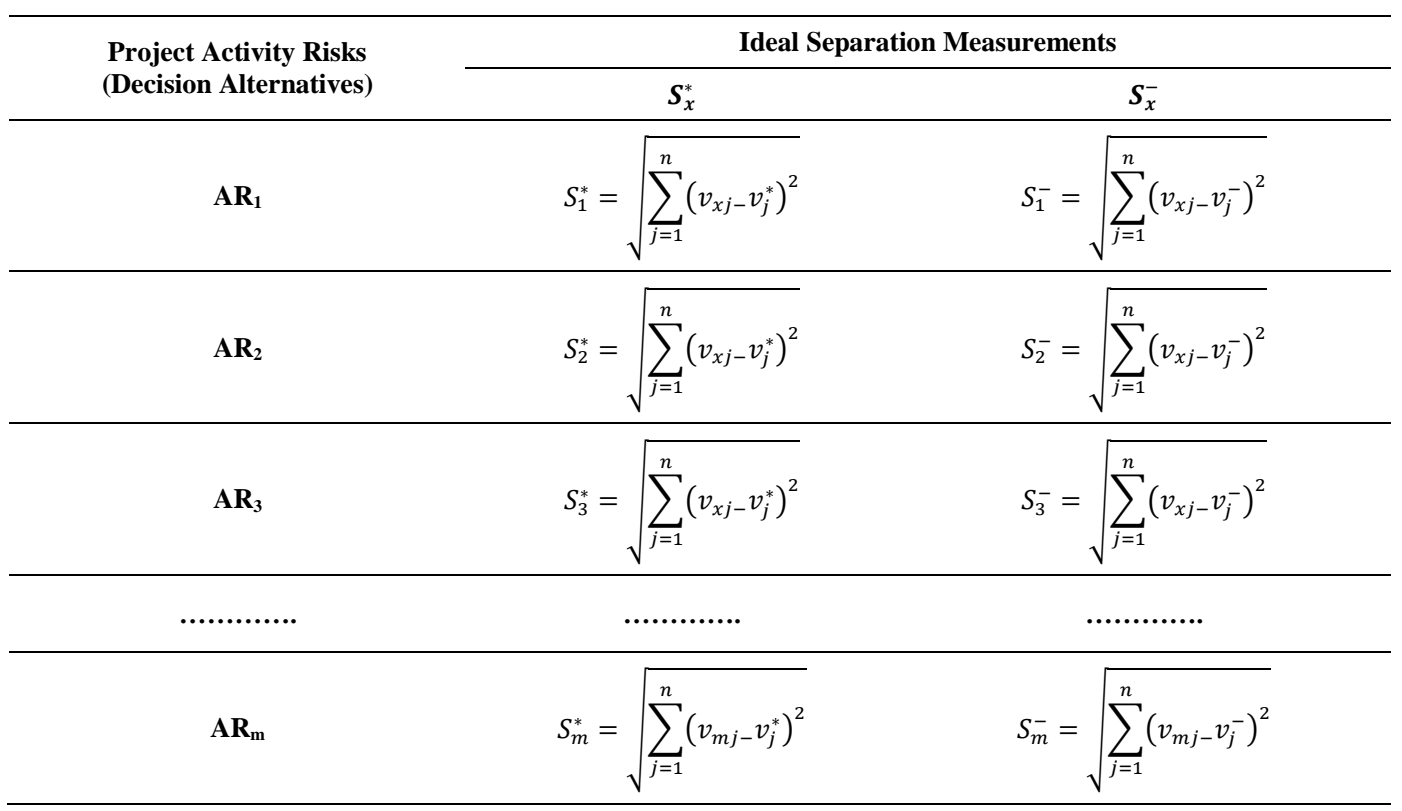


- Step 12: In the last step, relative distances of every decision alternatives to ideal solutions are calculated.

$C_{x}^{*}=\frac{s_{x}^{-}}{S_{x}^{*}+S_{x}^{-}}$

Table 1. Decision alternatives and relative distance measure.

\begin{tabular}{cc}
\hline Decision Alternatives & $S^{*}$ \\
\hline $\mathbf{A R}_{1}$ & $C_{1}^{*}=\frac{S_{1}^{-}}{S_{1}^{*}+S_{1}^{-}}$ \\
$\mathrm{AR}_{2}$ & $C_{2}^{*}=\frac{S_{2}^{-}}{S_{2}^{*}+S_{2}^{-}}$ \\
$\mathrm{AR}_{3}$ & $C_{3}^{*}=\frac{S_{3}^{-}}{S_{3}^{*}+S_{3}^{-}}$ \\
$\ldots \ldots \ldots .$. & $\cdots \cdots \cdots \cdots$ \\
$\mathbf{A R}_{\mathrm{m}}$ & $C_{m}^{*}=\frac{S_{m}^{-}}{S_{m}^{*}+S_{m}^{-}}$ \\
\hline
\end{tabular}

At the end of TOPSIS calculations $C_{x}^{*}$ values of activity risks ARx are sequenced in increasing order. Technically, $C_{x}^{*}$ values vary between $[0,1]$. According to TOPSIS solution of this novel project activity risk prioritization largest $C_{x}^{*}$ value implies most vital activity risk of project. Measurement of this risk is very important for success of this project. On the other hand, smallest $C_{x}^{*}$ value implies the most insignificant activity risk of project. Measurement of this risk may not be worth. Resources allocated to diminish the damage of this risk can be shifted to other more important risks. Other risks which are ranked by TOPSIS method can be evaluated with same logic. Smaller $C_{x}^{*}$ implies more important risks and bigger $C_{x}^{*}$ values imply less important risks.

\section{4- Case Study}

In this study AHP and TOPSIS method are combined to developed new method. In the application of this method, a case study approach is followed. The case study, based on what it Yin (2002) [22] says, is considered to be an exploration of an existing noticeable fact through applying it in a practical setting, especially in cases when there is ambiguity in the difference between the setting and the fact. In this sense, "Global Furniture Ltd." which is established in Istanbul, Turkey is chosen as a case to apply newly developed model. This company is planning to enter a Bulgarian market, and the new decision making model is applied to this market entry decisions.

Global Furniture Ltd. is operating in Istanbul, Turkey. The company was established in 1980 and operates through its more than 100 employees. The company is mainly producing living room furniture. The company is operating in the mid-market and aims to provide good quality products for affordable prices. Recently, company managers decided to enter Bulgarian market which looks like a growth opportunity for the company. In this context, in this part, the newly developed decision making method will be applied to the company's new market entry project.

\section{4-1- Application of Project Activity Risk Prioritization via AHP-Stochastic TOPSIS Hybrid Algorithm to New Living Room Furniture Market Entry Project}

In this part AHP-Stochastic TOPSIS algorithm is applied to new product market entry project. A furniture manufacturer tends to design new living room furniture and make it enter with the best price and best cost, as much as they can achieve. Thus, this company project the living room furniture design and market entry process, also they need to assess and analyze possible project risks. To achieve this job, the use AHP-TOPSIS hybrid algorithm to prioritize activity risks in an analytic way. Application steps are expressed below;

- Step 1: Living room furniture design and market entry project involves three work packages. Aim of project is introducing competitive and creditable living room furniture to market.

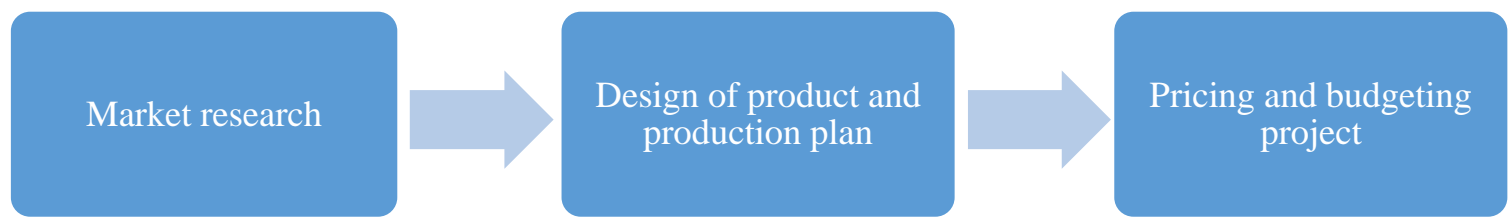

Figure 7. Work packages of living room furniture design and market entry project. 
- Step 2: Constructing AHP model to prioritize work packages with respect to their influence on project time, project output quality and project cost.

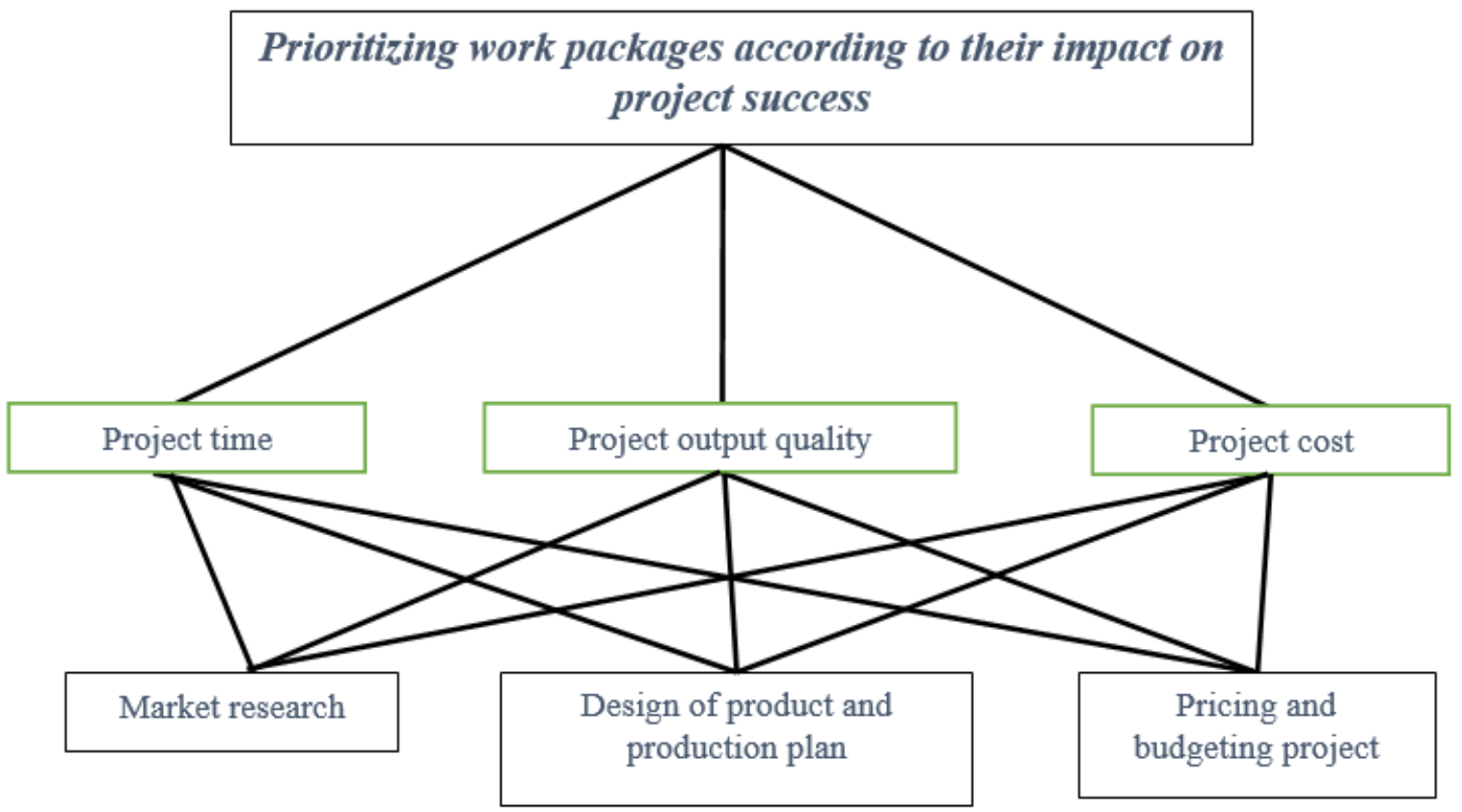

Figure 8. AHP model of work package prioritization problem.

Table 8. Global AHP priorities of work packages.

\begin{tabular}{cc}
\hline \multicolumn{2}{c}{ Global AHP priorities of work packages } \\
\hline Alternatives & Priority \\
\hline Market research & 0,155 \\
Design of product and production plan & 0,64 \\
Pricing and budgeting project & 0,205 \\
\hline
\end{tabular}

- Step 3: Work packages are broken down into sub-activities which can be used for constructing project network.

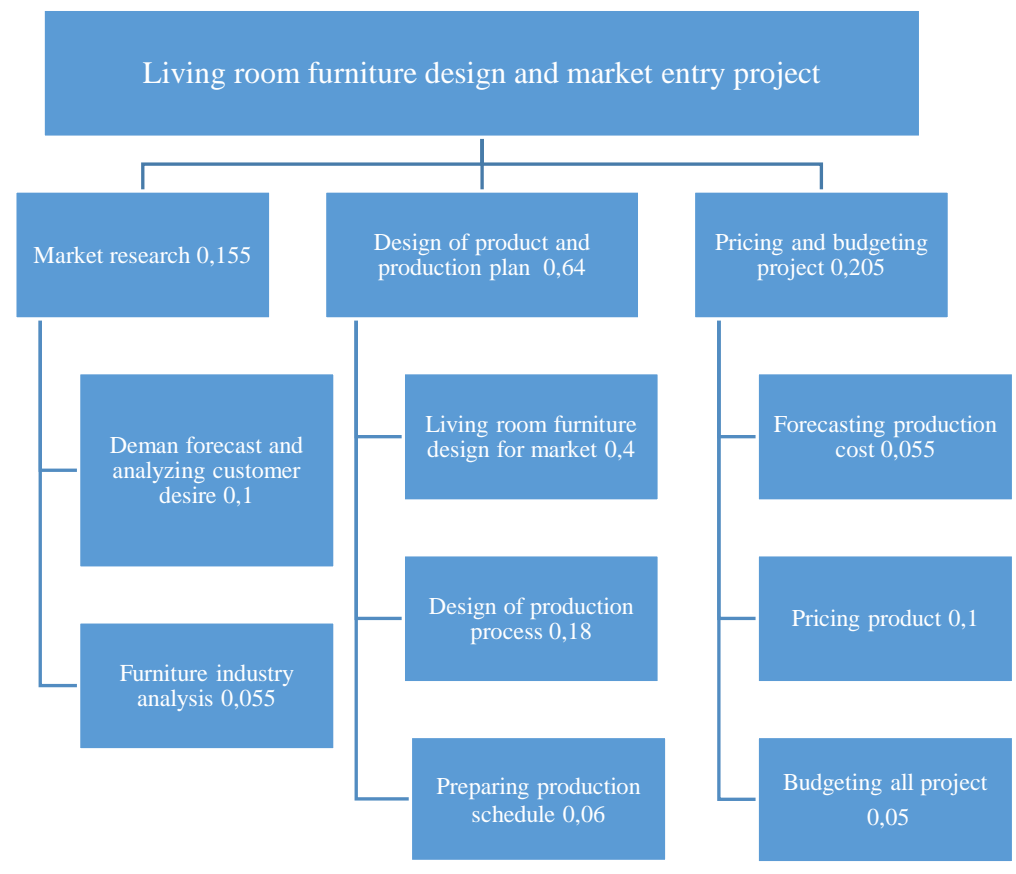

Figure 9. Work breakdown structure of project and priorities of work packages and their sub-activities. 
Table 9. Activity relationship table of project.

\begin{tabular}{lcc}
\hline \multicolumn{1}{c}{ Project activity } & Activity Code & Predecessor \\
\hline Demand forecast and analyzing customer desire & $\mathrm{A}$ & - \\
Furniture industry analysis & $\mathrm{B}$ & - \\
Living room furniture design for market & $\mathrm{C}$ & $\mathrm{B}, \mathrm{A}$ \\
Design of production process & $\mathrm{D}$ & $\mathrm{C}$ \\
Preparing production Schedule & $\mathrm{E}$ & $\mathrm{D}$ \\
Forecasting production cost & $\mathrm{F}$ & $\mathrm{D}$ \\
Pricing product & $\mathrm{G}$ & $\mathrm{F}$ \\
Budgeting all project & $\mathrm{H}$ & $\mathrm{F}$ \\
\hline
\end{tabular}

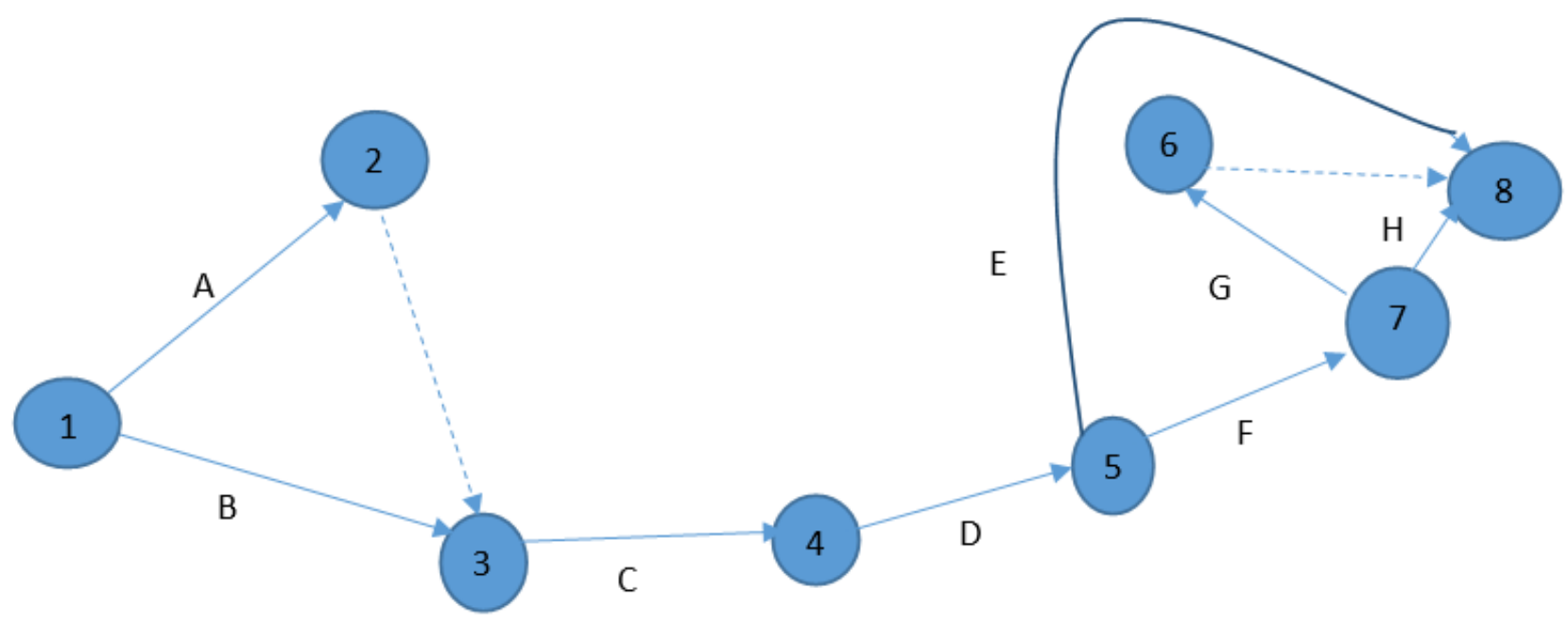

Figure 10. Project network of Living room furniture design and market entry project.

- Step 4: This step is determining the project activity parameters which are project output quality indicators, project time and project cost. Those tables are also includes importance weights of project activity parameters.

Table 2. TOPSIS table information of demand forecast and analysing customer desire.

\begin{tabular}{|c|c|c|c|c|}
\hline \multicolumn{5}{|c|}{ Demand forecast and analyzing customer desire } \\
\hline Project activity risks & Likelihood of risk & $\begin{array}{l}\text { Project activity } \\
\text { parameters }\end{array}$ & $\begin{array}{l}\text { Weights of project } \\
\text { activity parameters }\end{array}$ & $\begin{array}{l}\text { Performance indicator of } \\
\text { project activity parameters }\end{array}$ \\
\hline $\begin{array}{l}\left(\mathrm{AR}_{1}\right) \text { Selecting less and non- } \\
\text { homogeneous sample }\end{array}$ & $\left(\mathrm{LAR}_{1}\right) 15 \%$ & $\begin{array}{l}\left(\mathrm{AOQ}_{11}\right) \text { Forecasting } \\
\text { accuracy of living } \\
\text { room furniture demand }\end{array}$ & $\mathrm{WAOQ}_{11}=0,06$ & Forecasting error percentage. \\
\hline $\begin{array}{l}\left(\mathrm{AR}_{2}\right) \text { Applying unsuitable } \\
\text { forecasting method }\end{array}$ & $\left(\mathrm{LAR}_{2}\right) 20 \%$ & $\left(\mathrm{AC}_{1}\right)$ Activity cost & $\mathrm{WAC}_{1}=0,02$ & Activity cost increase \\
\hline $\begin{array}{l}\left(\mathrm{AR}_{3}\right) \text { Misunderstanding of customer } \\
\text { desire of new living room furniture }\end{array}$ & $\left(\mathrm{LAR}_{3}\right) 15 \%$ & $\left(\mathrm{AT}_{1}\right)$ Activity time & $\mathrm{WAT}_{1}=0,02$ & Activity time increase \\
\hline
\end{tabular}

Table 3. TOPSIS table information of furniture industry analysis.

\begin{tabular}{ccccc}
\hline Project activity risks & $\begin{array}{c}\text { Likelihood of } \\
\text { risk }\end{array}$ & $\begin{array}{c}\text { Project activity } \\
\text { parameters }\end{array}$ & $\begin{array}{c}\text { Weights of project } \\
\text { activity parameters }\end{array}$ & $\begin{array}{c}\text { Performance indicator of } \\
\text { project activity parameters }\end{array}$ \\
\hline $\begin{array}{c}\left(\mathrm{AR}_{4}\right) \text { Selecting unsuitable } \\
\text { industry analysis team }\end{array}$ & $\left(\mathrm{LAR}_{4}\right) 10 \%$ & $\begin{array}{c}\left(\mathrm{AOQ}_{21}\right) \text { Analyzed amount } \\
\text { of furniture industry }\end{array}$ & WAOQ $_{21}=0,015$ & $\begin{array}{c}\text { Percentage of regional furniture } \\
\text { industry not analyzed }(\%)\end{array}$ \\
$\begin{array}{c}\left(\mathrm{AR}_{5}\right) \text { Refusal of competitors to } \\
\text { give information about industry }\end{array}$ & $\left(\mathrm{LAR}_{5}\right) 35 \%$ & $\left(\mathrm{AC}_{2}\right)$ Activity cost & $\mathrm{WAC}_{2}=0,02$ & Activity cost increase $(\$)$ \\
\end{tabular}


Table 4. TOPSIS table information of living room furniture design for market.

\begin{tabular}{|c|c|c|c|c|}
\hline \multicolumn{5}{|c|}{ Living room furniture design for market } \\
\hline Project activity risks & $\begin{array}{l}\text { Likelihood of } \\
\text { risk }\end{array}$ & Project activity parameters & $\begin{array}{l}\text { Weights of project } \\
\text { activity parameters }\end{array}$ & $\begin{array}{l}\text { Performance indicator of } \\
\text { project activity parameters }\end{array}$ \\
\hline $\begin{array}{l}\left(\mathrm{AR}_{6}\right) \text { Probability of not finding } \\
\text { a good furniture design team }\end{array}$ & $\left(\mathrm{LAR}_{5}\right) 20 \%$ & $\begin{array}{c}\left(\mathrm{AOQ}_{31}\right) \text { Customer preference of } \\
\text { new furniture }\end{array}$ & $\mathrm{WAOQ}_{31}=0,15$ & $\begin{array}{l}\text { Percentage of designing } \\
\text { undesirable furniture for } \\
\text { customer }(\%)\end{array}$ \\
\hline \multirow[t]{3}{*}{$\begin{array}{l}\left(\mathrm{AR}_{7}\right) \text { Probability of not finding } \\
\text { a suitable suppliers in terms of } \\
\text { cost and quality }\end{array}$} & $\left(\mathrm{LAR}_{6}\right) 25 \%$ & $\begin{array}{l}\left(\mathrm{AOQ}_{32}\right) \text { Usage amount of } \\
\text { domestic resources and technology } \\
\text { needed for designed furniture }\end{array}$ & $\mathrm{WAOQ}_{32}=0,15$ & $\begin{array}{l}\text { Percentage of domestic } \\
\text { resources and technology. (\%) }\end{array}$ \\
\hline & & $\left(\mathrm{AC}_{3}\right)$ Activity cost & $\mathrm{WAC}_{3}=0,05$ & Activity cost increase (\$) \\
\hline & & $\left(\mathrm{AT}_{3}\right)$ Activity time & $\mathrm{WAT}_{3}=0,05$ & Activity time increase (days) \\
\hline
\end{tabular}

Table 5. TOPSIS information table of design of production process.

\begin{tabular}{|c|c|c|c|c|}
\hline \multicolumn{5}{|c|}{ Design of production process } \\
\hline Project activity risks & $\begin{array}{l}\text { Likelihood of } \\
\text { risk }\end{array}$ & Project activity parameters & $\begin{array}{l}\text { Weights of project } \\
\text { activity parameters }\end{array}$ & $\begin{array}{l}\text { Performance indicator of } \\
\text { project activity parameters }\end{array}$ \\
\hline $\begin{array}{l}\left(\mathrm{AR}_{8}\right) \text { Probability of not } \\
\text { matching the new designed } \\
\text { furniture and technology of } \\
\text { production process }\end{array}$ & $\left(\mathrm{LAR}_{7}\right) 10 \%$ & $\begin{array}{l}\left(\mathrm{AOQ}_{41}\right) \text { Manufacturing capacity of } \\
\text { production process per month }\end{array}$ & $\mathrm{WAOQ}_{41}=0,02$ & $\begin{array}{l}\text { Number of living room furniture } \\
\text { manufactured set per month } \\
\text { (number) }\end{array}$ \\
\hline \multirow[t]{4}{*}{$\begin{array}{l}\left(\mathrm{AR}_{9}\right) \text { Probability of not } \\
\text { finding suitable process } \\
\text { technology }\end{array}$} & $\left(\mathrm{LAR}_{8}\right) 5 \%$ & $\begin{array}{l}\left(\mathrm{AOQ}_{42}\right) \text { Number of labor need for } \\
\text { production process. }\end{array}$ & $\mathrm{WAOQ}_{42}=0,02$ & $\begin{array}{l}\text { Number of labor need for } \\
\text { production process. (number) }\end{array}$ \\
\hline & & $\begin{array}{c}\left(\mathrm{AOQ}_{43}\right) \text { Unit mass production cost } \\
\text { of product }\end{array}$ & $\mathrm{WAOQ}_{43}=0,04$ & $\begin{array}{l}\text { Unit mass production cost of } \\
\text { product }(\$)\end{array}$ \\
\hline & & $\left(\mathrm{AC}_{4}\right)$ Activity cost & $\mathrm{WAC}_{4}=0,05$ & Activity cost increase $(\$)$ \\
\hline & & $\left(\mathrm{AT}_{4}\right)$ Activity time & $\mathrm{WAT}_{4}=0,05$ & Activity time increase (days) \\
\hline
\end{tabular}

Table 6. TOPSIS information table of preparing production schedule.

\begin{tabular}{|c|c|c|c|c|}
\hline \multicolumn{5}{|c|}{ Preparing production schedule } \\
\hline Project activity risks & Likelihood of risk & Project activity Parameters & $\begin{array}{l}\text { Weights of project } \\
\text { activity parameters }\end{array}$ & $\begin{array}{c}\text { Performance indicator of } \\
\text { project activity parameters }\end{array}$ \\
\hline $\begin{array}{c}\left(\mathrm{AR}_{10}\right) \text { Poor capacity } \\
\text { plan }\end{array}$ & $\left(\mathrm{LAR}_{9}\right) 15 \%$ & $\begin{array}{l}\left(\mathrm{AOQ}_{51}\right) \text { Number of late } \\
\text { furniture delivery to customer }\end{array}$ & $\mathrm{WAOQ}_{51}=0,02$ & $\begin{array}{l}\text { Number of late delivery per } \\
\text { month (number) }\end{array}$ \\
\hline \multirow[t]{3}{*}{$\begin{array}{l}\left(\mathrm{AR}_{11}\right) \text { Poor materials } \\
\text { requirement plan }\end{array}$} & $\left(\mathrm{LAR}_{10}\right) 5 \%$ & $\begin{array}{l}\left(\mathrm{AOQ}_{52}\right) \text { Average monthly } \\
\text { wood inventory }\end{array}$ & $\mathrm{WAOQ}_{52}=0,02$ & $\begin{array}{l}\text { tons of kept in inventory per } \\
\text { month (tons) }\end{array}$ \\
\hline & & $\left(\mathrm{AC}_{5}\right)$ Activity cost & $\mathrm{WAC}_{5}=0,01$ & Activity cost increase (\$) \\
\hline & & $\left(\mathrm{AT}_{5}\right)$ Activity time & $\mathrm{WAT}_{5}=0,01$ & Activity time increase (days) \\
\hline
\end{tabular}

Table 7. TOPSIS table of forecasting production cost.

\begin{tabular}{ccccc}
\hline & Forecasting production cost \\
\hline Project activity risks & Likelihood of risk & Project activity parameters & $\begin{array}{c}\text { Weights of project } \\
\text { activity parameters }\end{array}$ & $\begin{array}{c}\text { Performance indicator of } \\
\text { project activity parameters }\end{array}$ \\
\hline $\begin{array}{c}\left(\mathrm{AR}_{12}\right) \text { Insufficient } \\
\text { data collection }\end{array}$ & $\left(\mathrm{LAR}_{11}\right) 10 \%$ & $\begin{array}{c}\left(\mathrm{AOQ}_{61}\right) \text { Forecasting accuracy } \\
\text { of production cost }\end{array}$ & WAOQ $_{61=0,04}$ & $\begin{array}{c}\text { Percentage error of forecasting } \\
\text { production cost }(\%)\end{array}$ \\
$\begin{array}{c}\left(\mathrm{AR}_{13}\right) \text { Insufficient } \\
\text { method selection }\end{array}$ & $\left(\mathrm{LAR}_{12}\right) 15 \%$ & $\mathrm{WAC}_{6}=0,01$ & Activity cost increase $\left.(\$)_{6}\right)$ Activity cost \\
& & $\left(\mathrm{AT}_{6}\right)$ Activity time & $\mathrm{WAT}_{6}=0,005$ & Activity time increase $($ days $)$ \\
\hline
\end{tabular}


Table 8.TOPSIS table information of pricing product.

\begin{tabular}{ccccc}
\hline Project activity risks & $\begin{array}{c}\text { Likelihood } \\
\text { of risk }\end{array}$ & Project activity parameters & $\begin{array}{c}\text { Weights of project } \\
\text { activity parameters }\end{array}$ & $\begin{array}{c}\text { Performance indicator of } \\
\text { project activity parameters }\end{array}$ \\
\hline $\begin{array}{c}\left(\mathrm{AR}_{14}\right) \text { Probability of pricing } \\
\text { higher than its actual value }\end{array}$ & $\left(\mathrm{LAR}_{13}\right) 15 \%$ & $\begin{array}{c}\left(\mathrm{AOQ}_{71}\right) \text { Amount of revenue gaining } \\
\text { from new product per month }\end{array}$ & WAOQ $_{71}=0,08$ \\
\hline $\begin{array}{c}\left(\mathrm{AR}_{15}\right) \text { Probability of pricing } \\
\text { lower than its actual value }\end{array}$ & $\left(\mathrm{LAR}_{14}\right) 5 \%$ & $\left(\mathrm{AC}_{7}\right)$ Activity cost & WAC $_{7}=0,01$ & Activity cost increase $(\$)^{\text {renue per month }(\$)}$ \\
\hline
\end{tabular}

Table 9. TOPSIS table information of budgeting all project.

\begin{tabular}{|c|c|c|c|c|}
\hline \multicolumn{5}{|c|}{ Budgeting all project } \\
\hline Project activity risks & Likelihood of risk & Project activity parameters & $\begin{array}{l}\text { Weights of project } \\
\text { activity parameters }\end{array}$ & $\begin{array}{l}\text { Performance indicator of } \\
\text { project activity parameters }\end{array}$ \\
\hline \multirow[t]{3}{*}{$\begin{array}{l}\left(\mathrm{AR}_{16}\right) \text { Insufficient } \\
\text { resource allocation }\end{array}$} & $\left(\mathrm{LAR}_{15}\right) 10 \%$ & $\left(\mathrm{AOQ}_{81}\right)$ Amount of budget deficit & $\mathrm{WAOQ}_{81}=0,03$ & Amount of budget deficit (\$) \\
\hline & & $\left(\mathrm{AC}_{8}\right)$ Activity cost & $\mathrm{WAC}_{8}=0,01$ & Activity cost increase $(\$)$ \\
\hline & & $\left(\mathrm{AT}_{8}\right)$ Activity time & $\mathrm{WAT}_{8}=0,01$ & Activity time increase (days) \\
\hline
\end{tabular}

- Step 5: This step is constructing TOPSIS table of model.

Table 10. Dimension of initial TOPSIS table of model.

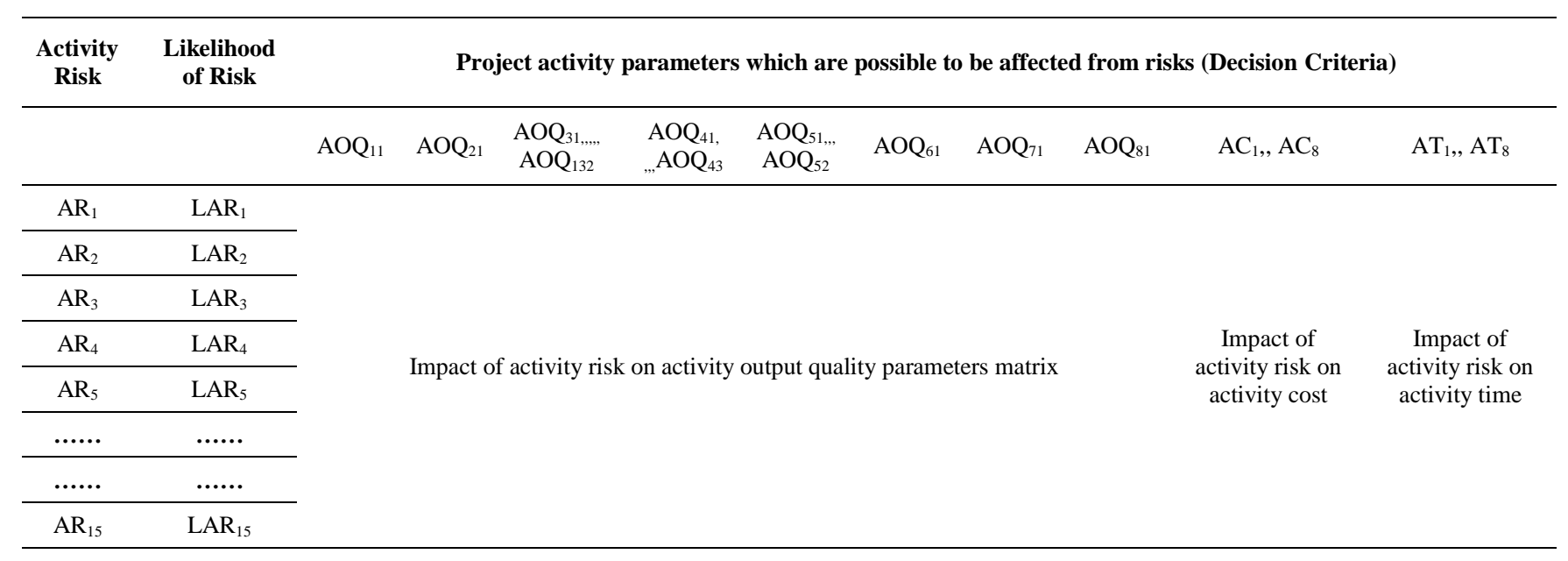

- Step 6: In this application, TOPSIS calculations are made by excel macro software. Project management team determines TOPSIS table inputs. 
Table 11. TOPSIS table and solution scores of application model.

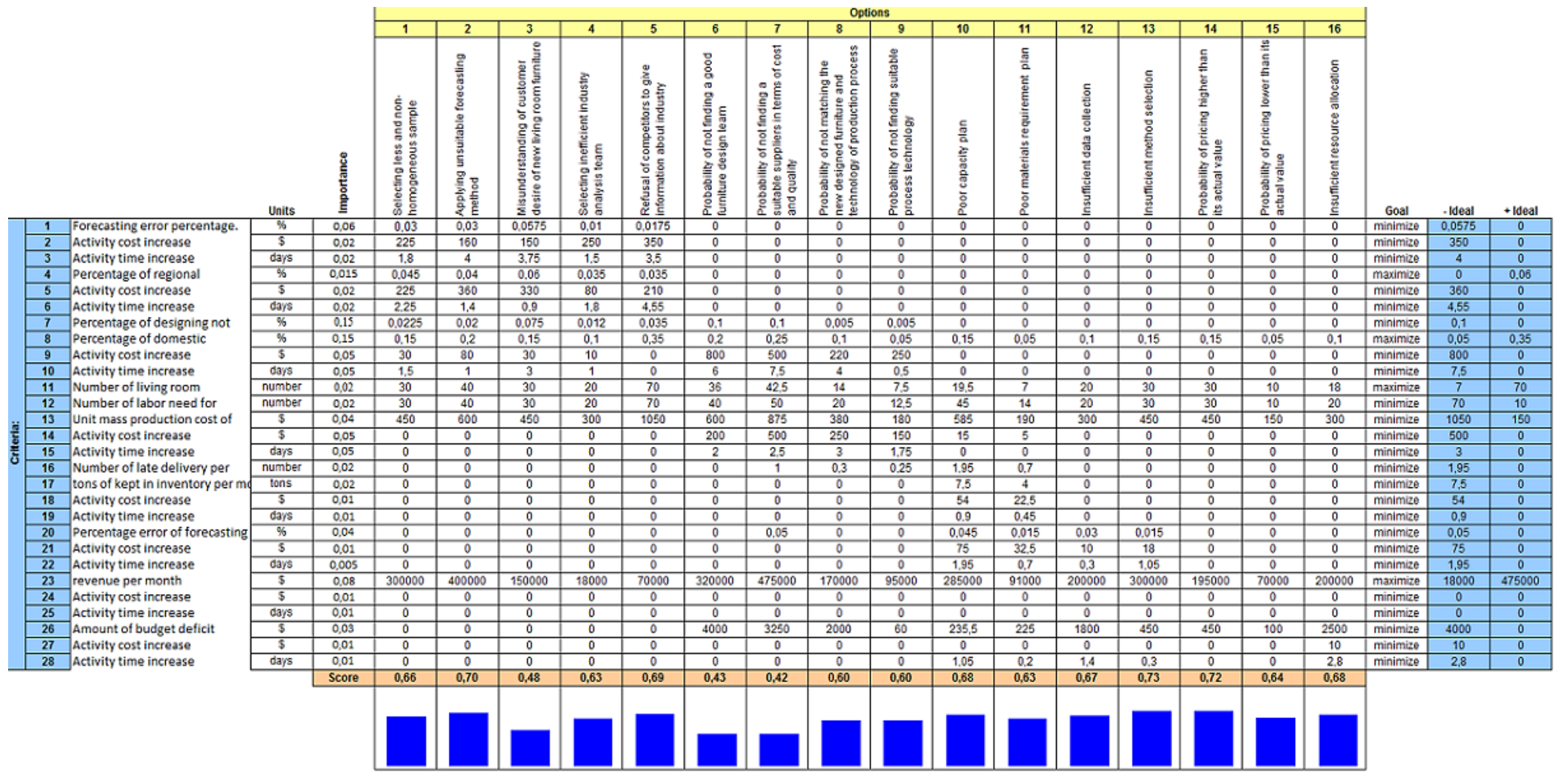


Table 12. Rank and $C_{x}^{*}$ values of activity risks.

\begin{tabular}{ccc}
\hline Decision Alternatives & $\boldsymbol{C}_{\boldsymbol{x}}^{*}$ & Priority rank of activity risk \\
\hline $\mathrm{AR}_{1}$ & $C_{1}^{*}=0,66$ & 8 \\
$\mathrm{AR}_{2}$ & $C_{2}^{*}=0,7$ & 3 \\
$\mathrm{AR}_{3}$ & $C_{3}^{*}=0,48$ & 14 \\
$\mathrm{AR}_{4}$ & $C_{4}^{*}=0,63$ & 11 \\
$\mathrm{AR}_{5}$ & $C_{5}^{*}=0,69$ & 4 \\
$\mathrm{AR}_{6}$ & $C_{6}^{*}=0,43$ & 15 \\
$\mathrm{AR}_{7}$ & $C_{7}^{*}=0,42$ & 16 \\
$\mathrm{AR}_{8}$ & $C_{8}^{*}=0,6$ & 12 \\
$\mathrm{AR}_{9}$ & $C_{9}^{*}=0,6$ & 13 \\
$\mathrm{AR}_{10}$ & $C_{10}^{*}=0,68$ & 5 \\
$\mathrm{AR}_{11}$ & $C_{11}^{*}=0,63$ & 10 \\
$\mathrm{AR}_{12}$ & $C_{12}^{*}=0,67$ & 7 \\
$\mathrm{AR}_{13}$ & $C_{13}^{*}=0,73$ & 1 \\
$\mathrm{AR}_{14}$ & $C_{14}^{*}=0,72$ & 2 \\
$\mathrm{AR}_{15}$ & $C_{15}^{*}=0,64$ & 9 \\
$\mathrm{AR}_{16}$ & $C_{16}^{*}=0,68$ & 6 \\
\hline
\end{tabular}

\section{5- Results}

Application part of study is carried out by decision model analyst, furniture development experts, manufacturing managers and company finance managers. During first layer of case study some AHP pairwise comparison workshops are conducted. Group decision making principles are considered during that process. AHP part of model emerges the most risky (that means; the project phase whose risks are most remarkable for project quality, project cost and project implementation time) project phase. Results of AHP model implies that the decision makers come to an agreement on design of product and production plan phase has the most important risks that may affect project features. Because they think that this phase is the heart of project. It includes design characteristics and production technology selection. These plans takes more time and effort than market research and pricing-budgeting task. AHP give \%64 importance grade to it. When it comes to pricing and budgeting phase; results of AHP represents that risks of this phase has second greatest importance because of economic and financial volatility in both Bulgaria and Turkey. AHP model give $\% 20,5$ risk importance grade. Decision makers always think that Market research phase is a routine task that can be conducted with similar process in all countries so AHP model gives \%15,5 grade to that. After implementing first layer of model, those grade are distributed to project activities. Design of product and production plan phase is divided to two activities that are living room furniture design for market and design of production process. At this point, furniture development experts doubt that in a foreign country, sometimes it is hard to meet product design and customer requirements that may vary according to cultural difference. Therefore, "Living room furniture design" for Bulgarian market project activity considered as the riskiest project activity of all. On the other hand, company management thinks that they have skillful finance department, so they consider furniture industry analysis and budgeting project activities.

In second layer of model, TOPSIS method is customized for this case study. Particular and possible risks that will be ranked at the end of the process are assigned to project activities. Project activity parameters which deal with cost, quality and time is derived and assigned in TOPSIS model as decision criteria. This process increases the sensitivity of that risk ranking model. These detailed risks are evaluated and prioritized according to all project activity parameters as a holistic approach.

Results TOPSIS part of method Table 19 indicates that "(AR13) Insufficient method selection” while forecasting production cost and "(AR14) Probability of pricing higher than its actual value" while pricing the new product are the most risky project activities. Because they think economic feasibility is the most important issue in new product development projects. Pricing and costing are the most vital facts that influence the economic sustainability of furniture production. Forecasting of production cost requires proper historical price data raw materials, labour, technology, and related economic aspects. These data are also supposed to be processed by suitable forecasting method. Because of cost variability in the country, it becomes more important to find a reliable estimation method to analyze variability and uncertainty. Besides that, because the estimation of production cost is risky, optimum pricing of new product becomes a hard job. Actually, Bulgarian furniture market is suitable for higher prices than optimum. As a result, this does not attract the mid-market customers. That reality also may cause a high risk. On the other hand 
they think that "(AR7) Probability of not finding a suitable suppliers in terms of cost and quality" and "(AR6) Probability of not finding a good furniture design team" are the least important project risks while making living room furniture design for market. Global Furniture Ltd is operating in İstanbul. That is the largest and most industrialized city of Turkey. Qualified suppliers for raw materials and technology. Hence, this company does not consider as critical risk. They think that city is also abundant in terms of human resource. "Probability of not finding a good furniture design team" is not a considerable risk for that project.

As it is mentioned before, some MCDM models are used for risk identification and other management issues. To compare our method development with recent studies, article of Indian researchers Bathrinath et al. (2020) were examined briefly in terms of their method development. They use a type of AHP and TOPSIS decision method. Their goal is to recognize and examine the possible risks that create accidents in textile industry. So, they use AHP TOPSIS method to rank risk factors in textile production process. Their decision support framework consists of two consecutive phase. In first phase, they determine risk factors that create accidents and alternatives in the textile industry which they of this information from the literature and from industry experts. They use a linguistic scale to acquire opinion on each factor and alternative. At the end of first phase, they finalize risk factors and alternatives by using Delphi method. In second phase MCDM methods are employed. They carry out an AHP model to find the most influential risk factor, and they use TOPSIS model to find critical alternative in the textile industry. This risk assessment model is comprehensive but this is an industry specific model. There is no real clear alternative model developed for whole project risk assessment at the project activity level, so far. That subject is open to improvement.

\section{6- Conclusions}

Application of AHP-Stochastic TOPSIS Hybrid Algorithm provides a platform that project risks could be analysed as quantitative. Traditional risk assessment methods such as risk matrix does not able analyse project risk quantitatively. Other methods that are summarized at literature survey of this article evaluate project risks quantitatively but they are not developed to analyse activity based project risks. Besides that they are developed to analyse risks of specific projects. On the contrary, AHP-Stochastic TOPSIS Hybrid Algorithm can be used for every type of projects once project activity risks, their probability of occurrence and project activity parameters known.

As a summary, benefits of performing AHP-Stochastic TOPSIS Hybrid Algorithm can be listed as below;

- It provides examining project risks at activity level. This allows being aware of more tangible risks.

- It provides emerging the activity output parameters and their quantitative boundary values which may be affected by activity risks.

- TOPSIS method allows project team to employ common mind while entering activity impacts on project activity parameters.

- It gives quick solution in comparison to qualitative methods.

- AHP and other weighting methods allow project management team to find out importance of project activity parameters.

Sequence and scores of activity risks help project management team while allocating resources to activity risks. Because to be aware of which risks are more vital effects this decision.

As conclusion, AHP-Stochastic TOPSIS Hybrid is an MCDM based analytical approach. Main success factor of this method is accuracy of determining impact of activity risks on activity quality parameter, activity cost and activity time. For future investigations, scenario analysis could be used to reveal impact relation between activity risk and activity parameters. Besides that uncertainty is very important factor at this risk prioritization problem; because sometimes we cannot be sure of impact value on activity parameters. Fuzzy TOPSIS method can be applied instead of TOPSIS method. Thus TOPSIS table data can be used to convert fuzzy values. This improvement provides to model partial effects of activity risks.

\section{7- Acknowledgments}

We are thankful to Global Furniture management team Ltd. for sharing their data with us and also their expert judgments.

\section{8- Conflict of Interest}

The author declares that there is no conflict of interests regarding the publication of this manuscript. In addition, the ethical issues, including plagiarism, informed consent, misconduct, data fabrication and/or falsification, double publication and/or submission, and redundancies have been completely observed by the authors. 


\section{9- References}

[1] Willumsen, Pelle, Josef Oehmen, Verena Stingl, and Joana Geraldi. "Value Creation through Project Risk Management." International Journal of Project Management 37, no. 5 (July 2019): 731-749. doi:10.1016/j.ijproman.2019.01.007.

[2] Hussey, D.E. "Portfolio Analysis: Practical Experience with the Directional Policy Matrix." Long Range Planning 11, no. 4 (August 1978): 2-8. doi:10.1016/0024-6301(78)90001-8.

[3] Anthony (Tony) Cox Jr, Louis. "What's wrong with risk matrices?." Risk Analysis: An International Journal 28, no. 2 (2008): 497-512. doi:10.1111/j.1539-6924.2008.01030.x.

[4] Dey, Prasanta Kumar. "Managing Project Risk Using Combined Analytic Hierarchy Process and Risk Map." Applied Soft Computing 10, no. 4 (September 2010): 990-1000. doi:10.1016/j.asoc.2010.03.010.

[5] Fu-zhou, Luo, and Gao Hong-yuan. "The Risk Assessment Model of BT Construction Engineering Project Financing." Systems Engineering Procedia 1 (2011): 169-173. doi:10.1016/j.sepro.2011.08.028.

[6] Liu, Peide, Xin Zhang, and Weilong Liu. "A Risk Evaluation Method for the High-Tech Project Investment Based on Uncertain Linguistic Variables." Technological Forecasting and Social Change 78, no. 1 (January 2011): 40-50. doi:10.1016/j.techfore.2010.04.011.1.

[7] Mousavi, S.M., R. Tavakkoli-Moghaddam, A. Azaron, S.M.H. Mojtahedi, and H. Hashemi. "Risk Assessment for Highway Projects Using Jackknife Technique." Expert Systems with Applications 38, no. 5 (May 2011): 5514-5524. doi:10.1016/j.eswa.2010.10.085.

[8] Tang, Wenbin, Feilian Zhang, Ze Ye, and Jingjing Li. "Research on Risk Evaluation in Urban Rail Transit Project." Procedia Engineering 15 (2011): 5094-5099. doi:10.1016/j.proeng.2011.08.945.

[9] Askari, M., and H.R. Shokrizade. "An Integrated Method for Ranking of Risk in BOT Projects.” Procedia - Social and Behavioral Sciences 109 (January 2014): 1390-1394. doi:10.1016/j.sbspro.2013.12.642.

[10] Zhao, Huiru, and Nana Li. "Risk Evaluation of a UHV Power Transmission Construction Project Based on a Cloud Model and FCE Method for Sustainability.” Sustainability 7, no. 3 (March 11, 2015): 2885-2914. doi:10.3390/su7032885.

[11] Muriana, Cinzia, and Giovanni Vizzini. "Project Risk Management: A Deterministic Quantitative Technique for Assessment and Mitigation." International Journal of Project Management 35, no. 3 (April 2017): 320-340. doi:10.1016/j.ijproman.2017.01.010.

[12] Wang, Le, Juan-juan Peng, and Jian-qiang Wang. “A Multi-Criteria Decision-Making Framework for Risk Ranking of Energy Performance Contracting Project under Picture Fuzzy Environment.” Journal of Cleaner Production 191 (August 2018): 105118. doi:10.1016/j.jclepro.2018.04.169.

[13] Urgilés, Paúl, Juan Claver, and Miguel A. Sebastián. "Methods for Quantitative Risks Analysis of Cost and Deadline Overruns in Complex Projects.” Procedia Manufacturing 41 (2019): 658-665. doi:10.1016/j.promfg.2019.09.055.

[14] Akbari Ahmadabadi, Ali, and Gholamreza Heravi. "Risk Assessment Framework of PPP-Megaprojects Focusing on Risk Interaction and Project Success." Transportation Research Part A: Policy and Practice 124 (June 2019): 169-188. doi:10.1016/j.tra.2019.03.011.

[15] Wu, Yunna, Ting Zhang, Kaifeng Chen, and Liqi Yi. "A Risk Assessment Framework of Seawater Pumped Hydro Storage Project in China Under Three Typical Public-Private Partnership Management Modes.” Journal of Energy Storage 32 (December 2020): 101753. doi:10.1016/j.est.2020.101753.

[16] Chebotareva, Galina, Wadim Strielkowski, and Dalia Streimikiene. "Risk Assessment in Renewable Energy Projects: A Case of Russia.” Journal of Cleaner Production 269 (October 2020): 122110. doi:10.1016/j.jclepro.2020.122110.

[17] Yuan, Ting, Pengcheng Xiang, Huaiyin Li, and Lei Zhang. "Identification of the Main Risks for International Rail Construction Projects Based on the Effects of Cost-Estimating Risks.” Journal of Cleaner Production 274 (November 2020): 122904. doi:10.1016/j.jclepro.2020.122904.

[18] Karahalios, Hristos. "The Application of the AHP-TOPSIS for Evaluating Ballast Water Treatment Systems by Ship Operators." Transportation Research Part D: Transport and Environment 52 (May 2017): $172-184$. doi:10.1016/j.trd.2017.03.001.

[19] Clifford Gray, \& Eric Larson. Project Management:The Managerial Process. (Stewart Mattson was fifth edition, Ed.) (4.edition). New York: Tim Vertovec, (2011).

[20] Tzeng, G.-H., \& Huang, J.-J., "Multiple Attribute Decision Making METHODS AND APPLICATIONS”,CRC press, 1th edition, (2011), ISBN: 978-1-4398-6157-8.

[21] Bhushan, N., \& Rai, K. Strategic Decision Making Applying the Analytic Hierarchy Process, 1th edition, (R. Roy, Ed.). U.S.A: Springer, (2004), ISBN: 9781852337568. 
[22] Yin, R.K. Case Study Research: Design and Methods. 2nd ed. London: Sage Publications, 3th edition, (2002), ISBN: 0761925538.

[23] Bathrinath, S., R.K.A. Bhalaji, and S. Saravanasankar. "Risk Analysis in Textile Industries Using AHP-TOPSIS.” Materials Today: Proceedings (May 2020). doi:10.1016/j.matpr.2020.04.722. 